\title{
Exploratory analysis of factors affecting on elite sport policy agenda setting phrase: Korean policies for elite sport athlete identification and development
}

\author{
Jeehyun Kang ${ }^{1}$, Jounghwa Son ${ }^{1}$, Hojin Shin ${ }^{1}$, \& Kisung Kwon ${ }^{2 *}$ \\ ${ }^{1}$ Seoul National University $\&{ }^{2}$ Kangwon National University
}

\begin{abstract}
[Purpose] This research aims to find out factors affecting policy at the agenda setting phrase. In order to analyze, Multiple Streams Framework(MSF) was adopted. Based on the frame, policy problem stream, policy alternative stream, political stream, window of policy change, and policy entrepreneur were applied for analytical framework. [Methods] The research conducted qualitative research with triangulation. Data were collected by in-depth interview and literature review including newspaper and previous researches. Content analysis was done for deriving factors. Then categorization and itemization were conducted. [Results] For the result, factors derived from the study were not different from factions mentioning at MSF. For policy problem stream perspective, this study draw International Sports Event Result, Hosting International Sports Event, Elite Sports Athletic Recruiting, Athletic and Sports Category Supporting System, Student Study Right/Student Human Right/Sports Academy, Policy Reality, Sport Expert/Institute Capability, Perception of Elite Sport Origin. factors. In the case of Policy Alternative Stream, This study finds Sports Related Administrative Organization Restructure, Supporting Policy of Elite Athletic Promoting Restructure, Parent Policy of Elite Athletic Promoting Policy, Parent Institution of Elite Athletic Promoting Law, Incentive Institution for Elite Athletic, Supporting Institution for Elite Athletic, Value of Policy Community for Sports Category Feature, Value of Policy Community for Sports Category Fairness, Budget, International Sports Event Hosting Policy factors. Lastly, in the political perspective, this study figures out Elite Sports for Nation Integration, Elite Sports for Enhancing National Prestige (North and South Replacement), Elite Sports for Inter Korean Reconciliation and Cooperation, Sports Related Administrative Organization Restructure Following Regime Change, Parent Policy Change of Elite Sports Following Regime Change factors. [Conclusions] The research has academic implication for generating elite sport policy agenda setting model as well as practical implication for urging effective participation of various practitioners concerning elite sport.
\end{abstract}

Key words: Elite sport policy, Elite sport athlete, Elite sport Athletic promoting policy, Multiple streams Framework, Policy agenda setting

논문 투고일 : 2020. 05. 14.

논문 수정일 : 2020. 06. 21.

게재 확정일 : 2020. 06. 30.

* 교신저자 : 권기성(k.kwon@kangwon.ac.kr).

\section{서 론}

한국은 주요 국제스포츠대회를 세계에서 최단기간에 모두 개최하였으며 각종 국제스포츠이벤트에서도 우수 한 성적을 거두고 있다. 처음으로 1948년 런던하계올림
\end{abstract}


픽에 대표팀을 파견하기 시작하여 국제스포츠대회에서 좋은 성적을 거둔 것을 바탕으로 국위선양을 목표로 전문 체육 정책이 발전해왔다. 이는 우수선수양성지원 정책으 로 구체화되어 1982년 국가대표후보선수 정책, 1993년 꿈나무선수 정책, 2010년 청소년대표선수 정책으로 이 어져 오고 있다(Jung, Ko, Kim, Kim, Seo, Nam, Ko, Lee, Kwon, \& Lee, 2017).

전문체육 정책 중에서도 우수선수양성지원 정책은 큰 비중을 차지하고 있으며, 그 하단에는 국가대표선수, 국 가대표후보선수, 청소년대표선수, 꿈나무선수 정책과 같 은 세부 정책들이 수립되어 실행되고 있다. 이와 관련하 여 Jung et al. (2017)는 우수선수양성지원 정책을 각 범주로 구분하여 해당 범주의 문제점을 제시하였으며 크 게 행정 및 조직, 체계, 선수, 지도자, 훈련, 지원 범주로 구분하였다. 각 범주의 대표적인 문제점들을 살펴보면 명 확한 사업의 목적 수립, 체계의 유기성 향상, 선수 및 지 도자 선발/평가/교육 체계의 발전, 훈련 프로그램 강화 및 지속적 선수 관리 체계, 예산 및 인력의 충원 등이었다.

이와 같이 우수선수양성지원 정책에서 유발되는 다양 한 문제점을 해결하기 위해서는 정책 수립의 가장 초기 단계라 할 수 있는 정책 의제설정 과정에 영향을 미치는 요인들을 살펴볼 필요가 있다. 이유는 의제설정 단계는 현실의 문제를 정책 의제화하는 단계이며 이는 정책의 출 발 시점이라 볼 수 있기 때문이다(Lee, Yun, Kwak, \& Lee, 2014). Kingdon (1984)은 다중흐름모형 (Multiple Streams Framework)을 제시하며 현실의 문제와 현상 이 어떠한 방식으로 정책 의제화 되는지에 대해 분석했 다. 다중흐름모형은 정책문제흐름, 정책대안흐름, 정치 흐름과 함께 정책 선도가를 구성 요인으로 두고 의제설정 과정을 설명한다. 정부는 이러한 의제설정 과정을 통해 문제 해결을 위한 정부 개입의 여부를 결정하게 된다.

본 연구에서는 다중흐름모형을 활용하여 전문체육 정 책 내 우수선수양성지원 관련 정책들이 최초 의제화되는 데 있어 영향을 미친 요인을 파악하고자 한다. 이를 통해 지금 현재 발생하고 있는 문제점들의 근원을 파악할 수 있을 것으로 판단하였다.

본 연구의 목적은 다중흐름모형을 바탕으로 전문체육 정책 내 우수선수양성지원 관련 정책 의제설정 과정에 영 향을 미친 요인을 도출하는 것이다. 이에 따른 연구 문제
는 첫째, 정책문제흐름 관점에서 의제설정과정에 영향을 미친 요인은 무엇인가?, 둘째, 정책대안흐름 관점에서 의 제설정 과정에 영향을 미친 요인은 무엇인가?, 셋째, 정 치흐름 관점에서 의제설정 과정에 영향을 미친 요인은 무 엇인가?이다.

본 연구 결과를 통해 우수선수양성지원 관련 정책 수 립 시 전문체육의 고유한 특성이 반영된 효율적 및 효과 적인 정책 설정의 기반을 마련할 수 있을 것으로 판단된 다. 더 나아가 실무적으로는 행정가, 선수, 지도자 등 각 각의 이해당사자 의견이 정책 의제설정 과정에 반영될 수 있는 방안을 모색하는데 기틀이 될 수 있다.

\section{이론적 배경}

\section{우수선수양성지원 정책}

다양한 전문체육 정책 중 하나인 우수선수양성지원 관 련 정책은 국가대표선수, 국가대표후보선수, 청소년대표 선수, 꿈나무선수로 구분된다. 국가대표선수 정책은 국 제 대회에서 우수한 성적을 거둬 국위 선양과 국민 통합 에 기여하는 것을 목표로 1948 년 시작되었다. 45 개 종 목, 1,232 명의 선수가 대상이며, 나이 제한은 없으며 선 발 기준은 경기력이다(Lee, Jung, Choi, Park, \& Jo, 2016).

국가대표후보선수 정책은 국가대표선수와의 상호 경 쟁을 통한 차세대 국가대표선수로서의 자질 개발 및 경기 력 향상, 국가대표선수 결원 시 우수한 기량을 갖춘 선수 를 즉시 충원하여 경기력 저하를 막는 것이 국가대표후보 선수 정책의 목표다. 29 종목 1,305 명의 선수가 대상이며 12 세부터 21 세까지가 선발들이며 선발 기준은 경기력과 성장 가능성이다(Jung et al., 2017).

청소년대표선수 정책은 훈련 및 경기 여건이 열악한 비인기 종목에 대한 지원을 통해 우수선수를 발굴하는 것 이 정책의 목적이다. 2010년 도입된 정책이며 29개 종목 904명의 선수가 대상이다. 만 13-18세의 경기력과 성장 가능성을 갖춘 선수가 선발 대상이 된다(Lee et al., 2016).

꿈나무선수 정책은 재능 있는 꿈나무선수의 조기 발굴 
과 육성을 통해 우수선수의 저변 확대에 기여하고, 차세 대 대표선수 충원의 기반이 되며 엘리트 체육의 장기적 발전에 밑거름이 되는 것을 정책 목표로 삼는다. 만 7세 부터 14세 체격, 체력, 경기력을 갖춘 선수가 선발 대상 이며 626 명의 선수가 정책의 수혜 대상이 된다 $(\mathrm{Lim}$, Lee, \& Lee, 2010).

Jung et al. (2017)이 제시한 우수선수양성지원 정책 의 문제점들을 구체적으로 살펴보면 우선 행정 및 조직 범주에서는 사업이 정확히 정의되고 있지 않으며 명확한 평가기준이 필요하고 종목단체의 역할이 모호하다는 측 면을 제기하였다. 체계 범주에서는 우수선수양성지원 정 책 세부정책들 간의 위계성, 형평성, 연계성 부족을 도출 하였다. 선수 범주에서는 선수 대상 및 선발과 함께 수급 의 어려움에 대한 문제를 제기하였다. 지도자 범주에서는 선발, 평가, 교육, 수급에 있어 전반적으로 체계성이 부족 하고 전문화 되어 있지 않다는 문제를 도출하였다. 훈련 범주에서는 프로그램이 전문화되어 있지 않고 선수 관리 의 지속성이 부족한 부분을 제시하였다. 마지막으로 지원 측면에서는 예산의 부족, 스포츠과학 지원의 어려움, 인 력 및 정보 관리의 문제를 문제점으로서 도출하였다.

이렇게 제기된 문제들을 다중흐름모형을 바탕으로 문 제, 정치, 정책 흐름으로 구체화하여 관련된 정책 의제설 정 과정에서 어떠한 요인들이 영향을 미쳤는지를 살펴보 고자 한다.

\section{다중흐름모형(Multiple Streams Framework)}

정책은 의제설정 과정을 통해 현실에 있던 다양한 문 제들 중 하나가 의제로 설정되고, 이후 정책 관련 의사결 정 과정을 통해 정책이 결정되며 집행, 평가되는 단계를 거친다(Lee et al., 2014). 그리고 평가 결과 및 현상의 변화 등을 반영하여 정책 변동의 필요성이 야기되며 이를 위해 다시 정책 형성, 결정, 집행, 평가 등의 단계로 순환 한다(Lee et al., 2014). 이러한 과정 속에서 정책이 수 립되고 집행되는데 있어 가장 최초의 단계는 의제 설정 단계라는 것을 알 수 있다.

의제설정 과정은 사회 내 존재하는 무수한 문제들 중 정부의 개입을 통해 해결해야 할 문제를 확정하는 단계이 다. 사회의 모든 현상은 자동적으로 문제화되는 것이 아
니며 의제화 단계를 거친다. 의제화를 위해서는 정책 결 정자의 상황에 대한 인식과 현상 변화에 대한 필요성이 반드시 자각되어야 한다(Choi \& Park, 2010). 정책 의 제설정 과정에는 크게 정책 문제의 특성, 정책 이해관계 자의 특성, 정치·경제·사회적 환경 등과 같은 요인이 영향 을 미칠 수 있다(Hong, 2013a).

Kingdon (1984)은 문제들이 어떻게 이슈화 되어 정 책 결정자들의 주목을 받게 되며 이것이 어떠한 과정을 통해 의제화 되는지에 대해 다중흐름모형을 통해 구체적 으로 설명하였다. 다중흐름모형의 구성요소는 정책문제 흐름(policy problem stream), 정책대안흐름(policy alternative stream), 정치흐름(political stream), 정책 변동의 창(window of policy change), 정책 선도가 (policy entrepreneur)다.

다중흐름모형에 따르면 정책 의제가 설정되는 절차는 다음과 같다. 지표의 변동 또는 위기, 재난 등으로 인해 정책문제흐름이 발생한다. 정책가의 활동, 이익집단의 개입, 예산 영향, 가치 수용 정도 등으로 설명되는 정책대 안흐름이 생긴다. 정권 교체, 국회 의석수 변화, 국민적 분위기 등으로 정치흐름이 나타난다. 정책 참여자들이 문 제를 인지하고 대안을 준비하고 있을 때 결정적인 정치흐 름이 나타나 정책의 창(policy window)을 연다는 것이 다중흐름모형이 제시하는 정책 의제 설정과정이다.

본 연구는 연구 문제 해결을 위해 정책 수립 및 실행에 있어 가장 첫 단계인 정책 의제화 과정에 집중하고자 한 다. 왜 특정 시기에 국가대표선수 정책이 탄생했으며, 국 가대표후보선수, 청소년대표선수, 꿈나무선수 정책이 각 각 어떻게 이슈화 되었고, 정책 결정자들의 관심을 끌어 정책 의제로 선정될 수 있었는지에 대해 알아보고자 한 다. 왜냐하면 의제 선정 단계가 정책 수립 및 실행의 가장 첫 단계이기 때문에 해당 시점에 대한 분석을 실시한다면 앞서 언급한 우수선수양성지원정책과 관련한 문제들의 근본 요인을 도출해 볼 수 있기 때문이다.

스포츠 정책과 관련하여 Park \& Park (2011)은 다중 흐름모형을 통해 지방 야구장의 낙후된 현상이 정책의제 화 된 사례를 연구하였으며, Hong (2013b)는 동 모형을 통해 학교스포츠 클럽에 대한 이슈가 어떻게 정책의제화 되었는지에 대한 연구를 했다. 이러한 맥락에서 Kingdon (1984)의 다중흐름모형 $(\mathrm{MSF})$ 에서 제시하는 정책문제 
흐름, 정책대안흐름, 정치흐름을 분석의 틀로 하여 한국 전문체육 정책 의제설정 과정에 영향을 미친 요인을 도출 해 보고자 한다.

\section{연구방법}

연구 수행을 위해 질적연구방법을 활용하였다. 질적 연 구 방법은 심도 있는 연구 진행에 앞서 기본적인 방향성 제시를 위해 활용 가능한 방법으로 활용된다(Altheide, 1996; Creswell, 2003; Eagleman, 2011). 다양한 질 적연구의 방법 중에서도 사례연구를 활용하였다. 이로 인 해 본 연구는 우수선수양성지원 관련 정책을 중심으로 전 문체육 정책의 의제설정 과정에 영향을 미치는 요인을 탐 험적으로 찾는 것에 초점을 맞추었다. 추후 연구들이 구 체적인 문제 해결을 위한 효율적 및 효과적 정책 수립을 할 수 있는 심화 연구의 방향 제시에 목적을 두고 있기에 적합한 연구 방법이라고 판단하였기 때문이다.

자료 수집에 있어 언론 기사 자료조사, 반구조화된 심 층면담, 선행연구 자료조사 방법을 활용하였다. 연구의 신뢰도 확보를 위해 심층면담 및 자료조사를 통한 결과 도출에 있어 세 명의 공동연구자가 세 가지 단계를 거치 는 과정을 실행하였다. 또한 신용성 (credibility), 의존성 (dependability), 확실성(conformability), 전이성 (transferability)으로 구성되는 진실성 측면(Krefting, 1991; Lincoln \& Guba, 1985)에서의 타당도 확보를 위 해 신용성, 의존성, 확실성의 경우는 언론 기사 자료조사, 심층면담, 선행연구 자료조사를 활용한 삼각검증법을 적 용하였다. 전이성과 관련하여 심층면담 및 자료조사 대상 선정에 있어 본 연구가 초점을 맞추고 있는 전문체육 더 나아가 우수선수양성지원 분야에 한정하였다.

\section{자료수집방법}

언론 기사 자료조사의 경우는 대표적 검색 포털 기준 전체 일간지 14 개의 지면 기사를 대상으로 하였다. 기사 검색 기간은 1990년 1월 1일부터 2019년 12월 10일로 설정하였다. 1990년으로 설정한 이유는 온라인으로 지 면 기사 검색이 가능한 최초 일자가 1990년 1월 1일이기
때문이다.

핵심 단어는 '엘리트 스포츠 정책', '스포츠 꿈나무 정 책', ‘우수 선수 양성 정책'으로 설정하였다. 본 연구의 목 적은 전문체육 정책 내 우수선수양성지원 관련 정책 의제 설정 과정에 영향을 미친 요인을 도출하는 것이므로 이와 관련한 핵심단어를 선정했다.

첫째, 엘리트 스포츠 정책을 키워드로 선정한 이유는 엘리트 스포츠가 선수, 국가대표선수 등 우수선수와 유관 한 단어 중 가장 포괄적인 단어이기 때문이다(Jung et al., 2017).

둘째, 스포츠 꿈나무 정책을 핵심단어로 선정한 이유 는 엘리트 선수로 정의되는 국가대표, 후보, 청소년대표, 꿈나무(Jung et al., 2017) 중 국가대표와 후보선수에 대한 정책은 엘리트 스포츠 정책 기사와 거의 동일하게 검색되는 반면 꿈나무 및 청소년 대표 정책에 대한 것은 엘리트 스포츠 정책을 핵심 단어로 검색하였을 때 거의 도출되지 않았다. 청소년 대표 정책은 2010년부터 시작 되어 언론기사를 통해 유의미한 자료를 수집하기 쉽지 않 았다. 반면 꿈나무의 경우 1993 년부터 시작되어 자료가 축적되어 있었을 뿐 아니라 엘리트 스포츠 정책을 핵심단 어로 검색했을 때 놓쳤던 자료들을 보완할 수 있었다.

셋째, 우수선수 양성정책을 핵심단어로 선정한 이유는 다음과 같다. 우수 선수란 국민진흥법시행령에 따라 국내 전국대회에서 대회신기록을 수립하거나 입상한 선수 또 는 국제경기대회에 파견된 선수를 의미한다. 따라서 가장 포괄적인 키워드로써 우수 선수 양성정책을 선정했다.

핵심 단어 외, 꼭 포함되어야 하는 단어의 경우는 다중 흐름모형의 주요 관점인 정책문제흐름, 정책대안흐름, 정치흐름을 고려하여 조직, 행정, 기관, 재정, 예산으로 설정하였다. 왜냐하면 한국의 체육 또는 스포츠 정책은 역대 정부의 체육행정 조직 및 정책과 재정지원 현황을 통해 가장 잘 드러나기 때문이다(Kim, 2000). 따라서 행 정 조직을 표현하는 단어인 조직, 행정, 기관과 재정지원 을 의미하는 재정, 예산을 꼭 포함하여야 하는 단어로 설 정했다. 이를 통해 총 269 건이 검색되었고 중복되거나 본 논문과 관련되지 않은 149 건의 기사를 제외한 120 건 의 기사를 분석 대상으로 하였다. 〈Table 1)에 검색 결과 를 제시하였다.

심층면담은 종목 단체 관련 지도자 20명을 대상으로 
Table 1. News Article Searching Results

\begin{tabular}{|c|c|c|c|}
\hline $\begin{array}{l}\text { Key } \\
\text { Word }\end{array}$ & $\begin{array}{c}\text { Word } \\
\text { (Must Include) }\end{array}$ & $\begin{array}{l}\text { \# of } \\
\text { Case }\end{array}$ & $\begin{array}{c}\text { MSF } \\
\text { Component } \\
\end{array}$ \\
\hline \multirow{5}{*}{$\begin{array}{l}\text { Elite } \\
\text { Sports } \\
\text { Policy }\end{array}$} & Organization & 29 & \multirow{3}{*}{$\begin{array}{l}\text { Political } \\
\text { / Problem }\end{array}$} \\
\hline & Administration & 19 & \\
\hline & Institute & 18 & \\
\hline & Finance & 8 & \multirow{2}{*}{$\begin{array}{l}\text { Policy } \\
\text { / Problem }\end{array}$} \\
\hline & Budget & 7 & \\
\hline \multirow{5}{*}{$\begin{array}{l}\text { Sport } \\
\text { Youth } \\
\text { Policy }\end{array}$} & Organization & 9 & \multirow{3}{*}{$\begin{array}{l}\text { Political } \\
\text { / Problem }\end{array}$} \\
\hline & Administration & 2 & \\
\hline & Institute & 6 & \\
\hline & Finance & 8 & \multirow{2}{*}{$\begin{array}{l}\text { Policy } \\
\text { / Problem }\end{array}$} \\
\hline & Budget & 3 & \\
\hline \multirow{5}{*}{$\begin{array}{c}\text { Exellent } \\
\text { Athletic } \\
\text { Training } \\
\text { Policy }\end{array}$} & Organization & 5 & \multirow{3}{*}{$\begin{array}{l}\text { Political } \\
\text { / Problem }\end{array}$} \\
\hline & Administration & 1 & \\
\hline & Institute & 2 & \\
\hline & Finance & 3 & \multirow{2}{*}{$\begin{array}{l}\text { Policy } \\
\text { / Problem }\end{array}$} \\
\hline & Budget & 3 & \\
\hline
\end{tabular}

Table 2. Depth Interview Subject Feature

\begin{tabular}{c|c|c}
\hline \hline No. & Sports Category Feature & Number of Subject \\
\hline 1 & Individual Single & 9 \\
\hline 2 & Individual Multi & 3 \\
\hline 3 & Team & 3 \\
\hline 4 & Combat & 5 \\
\hline \hline
\end{tabular}

반구조화된 형태로 실시했다. 전문체육 정책 내 우수선수 양성 정책의 실행 및 수혜와 직접 관련된 가장 대표적인 이해관계자이기 때문이다(Tak, 2018). 또한 정책이 수 립되면 정책 실행의 전반을 담당하기 때문이다.

심층면담은 〈Table 2 ᄀ과 같이 개인 단수 종목, 개인 복 합 종목, 구기종목, 격투종목으로 구분하여 대상을 선정 하였다. 익명으로 심층면담을 진행하여 구체적으로 종목 명은 제시할 수 없었다. 심층면담 질문지는 Kingdon (1984)의 다중흐름모형에 기반하여 전문체육 정책 의제 설정 과정에 영향을 미치는 문제, 정책, 정치의 흐름으로 각각 나누어 질문을 제시하여 구성했다.

선행연구를 통한 자료조사의 경우 영문 논문과 국문 논문으로 구분하여 자료를 수집하였다. 영문 논문의 경우 SPORTDISCUSS와 Scopus와 같은 데이터베이스를 활 용하였다. 국문 논문은 $\operatorname{RISS}($ 학술연구정보서비스)와
$\mathrm{KISS}$ (한국학술정보) 데이터베이스를 활용하였다. 연구 물의 형태는 전체내용이 제공되는 학술논문을 대상으로 하였다. 즉 잡지, 서적, 발표 자료는 제외했다. 잡지의 경 우 그 내용은 시리즈로 연재하는 등 흐름과 맥락을 고려 하기가 용이하지 않았으며, 발표 자료는 연구가 진행 중 인 경우도 포함되어 연구결과가 포함되지 않은 경우도 있 었다. 다만, 발표 자료의 경우 논문형식을 갖추고 연구 결 과까지 도출된 자료의 경우는 포함했다. 서적은 분량과 검색이 용이성이 떨어져 물리적인 이유로 배제했다.

국문 선행 연구의 경우 언어는 한국어로 제한하고 핵 심 단어는 '엘리트 스포츠 정책', '선수 양성'을 검색했다. 본 연구의 목적은 우수선수 양성 지원 관련 정책 의제설 정에 영향을 미친 요인을 도출하는 것이다. 엘리트 스포 츠 정책을 핵심단어로 선정한 이유는 앞서 언급한바와 같 이 엘리트 스포츠가 선수, 국가대표선수 등 우수선수와 유관한 단어 중 가장 포괄적인 단어이기 때문이다(Jung et al., 2017). 또한 선수 양성을 핵심단어로 설정한 이유 는 다양한 수준의 선수 양성에 대한 연구를 진행하면서 우수선수양성에 대한 비교 분석 등이 포함되거나 병행되 었을 것이라고 가정하여 자료 수집의 범위를 넓히기 위해 선수 양성을 핵심단어로 설정하였다.

$\mathrm{KISS}$ 검색하여 중복된 논문 10 개를 제외하여 340 개의 논문이 남았으며, RISS에서 동일한 방식으로 중복된 논 문 43개를 제외하고 590 개의 논문이 남았다. 두 검색엔진 의 각각의 결과 중 중복되는 258 개를 제외하여 672 개 논 문의 제목을 분석했다. 그 결과 113 개가 선택되었다.

우선, 선정한 분석대상을 다시 각기둥 흐름표 (prisma flow cart)를 활용한 문헌 선정 과정을 거쳐 분석할 자료 를 선별하였다. 둘째, 1 차에서 배제되지 않은 113 개의 논 문을 초록을 기준으로 연구 결과 및 결론에서 제시하고 있는 내용이 동 연구의 목적과의 부합여부를 살펴보았다. 그 결과 48 개의 논문이 배제되었다. 셋째, 선정된 65 개의 논문을 연구목적을 기준으로 질적평가를 했다. 영문 논문 분석과정과 마찬가지로 논문의 분석의 틀인 전문체육 정 책 의제 설정과정에 영향을 미친 문제, 정책, 정치의 흐름 을 기준으로 질적평가를 실시한 결과 19 개 논문을 제외 하여 〈Table 3 〉와 같이 최종적으로 46 개의 논문을 분석 대상으로 선정했다.

영문 선행 연구의 경우 언어는 영어로 제한하였으며 
Table 3. Final Selected Previous Research (Korean)

\begin{tabular}{|c|c|c|c|}
\hline & Research Title & Author (Year) & Publish Institute \\
\hline \multirow{26}{*}{$\begin{array}{c}\text { Korean } \\
(46)\end{array}$} & Toward a preliminary conceptualization of 'youth sport policy' & Jung, H. (2017) & Korean Institute of Sport Science \\
\hline & A Study of Systematical Problem about Elite Player Program & Lim, J. (1999) & KAHPERD \\
\hline & Exploring To The Direction of Korean Sport under " IMF " Economic Crisis & $\begin{array}{l}\text { Kim, S., Won, Y., Jung, H. } \\
\text { (1999) }\end{array}$ & KAHPERD \\
\hline & $\begin{array}{c}\text { A Study on the Development of Taekwondo in the Middle \& High Schools according to the Sports } \\
\text { Promotion Policies }\end{array}$ & Park, G., Kim, T. (2017) & $\begin{array}{l}\text { Korean Society for History of } \\
\text { Physical Education, Sport and } \\
\text { Dance }\end{array}$ \\
\hline & Legal Issues on the Enactment of the School Physical Education Promotion Act & Yeon, K. (2011) & $\begin{array}{l}\text { Korean Association of Sport and } \\
\text { Entertainment Law }\end{array}$ \\
\hline & A Study on the Sports Administration and Policy of Roh Moo Hyun Government & Se0, J., Park, C. (2011) & Korean Society of Sports Science \\
\hline & $\begin{array}{l}\text { Protection of Sport Rights and Legal Change for the National Sport Promotion ; A Study on Enactment } \\
\text { and Changing Process of National Sports Promotion Act }\end{array}$ & Son, S., Shin, H. (2008) & $\begin{array}{l}\text { Korean Association of Sport and } \\
\text { Entertainment Law }\end{array}$ \\
\hline & 국제경쟁력 강화를 위한 엘리트 체육 발전 모델 연구 (Korean Title Only) & $\begin{array}{l}\text { Lee, J., Kim, B., Kim, Y. } \\
\text { (2001) }\end{array}$ & Korean Institute of Sport Science \\
\hline & Exploring Policy Factors Leading to Elite Sporting Success: A Theoretical Review at the Meso-Level & Park, J., Han, S. (2011) & Korean Institute of Sport Science \\
\hline & $\begin{array}{l}\text { A Critical Review of the Literature on Sports and Physical Education Policies in the Third Republic of } \\
\text { the Republic of Korea }\end{array}$ & Lim, S., Hue, J. (2009) & $\begin{array}{l}\text { Korean Association of Sport and } \\
\text { Entertainment Law }\end{array}$ \\
\hline & $\begin{array}{l}\text { A Study on Background of Full Amendment about National Sports Promotion Act in the Fifth Republic } \\
\text { of Korea }\end{array}$ & Shin, H. (2009) & $\begin{array}{l}\text { Korean Association of Sport and } \\
\text { Entertainment Law }\end{array}$ \\
\hline & Present Status of Korea's Sports Talented Program & Kim, K., Choi, K. (2015) & Asian Journal of Youth Sport \\
\hline & $\begin{array}{l}\text { A Study on Elite Player Cultivation by the New Government and the Directions for Relevant National } \\
\text { Policy }\end{array}$ & $\begin{array}{l}\text { Kim, D., Yu, H., Song, G. } \\
(2008)\end{array}$ & KOREA SPORT SOCIETY \\
\hline & The Result, Problem and Future Challenges of Training Sport Gifted & $\begin{array}{l}\text { Lim, S., Lee, H., Lee, W. } \\
\text { (2010) }\end{array}$ & KAHPERD \\
\hline & Suggestions on selection profiles for early talent identification in sports & Lee, J., Kim, Y. (2004) & Korean Society of Sport Policy \\
\hline & 엘리트스포츠 정책의 바람직한 방향설정에 관한 연구 (Korean Title Only) & $\begin{array}{l}\text { Kim, S., Jang, S., Son, S. } \\
\text { (1993) }\end{array}$ & Gunsan University \\
\hline & 우리나라 엘리트 체육정책의 변화를 통해본 진흥 방향(Korean Title Only) & Lee, K. (1993) & Korea National Sport University \\
\hline & 우수선수 육성 실태: 차세대 국가대표양성 실종 우려된다 (Korean Title Only) & Hwang, H. (1991) & $\begin{array}{l}\text { Korean Sport \& Olympic } \\
\text { Committee }\end{array}$ \\
\hline & A Study on Intention and Background of Enactment of National Sports Promotion Act & Son, S., Shin, H. (2008a) & $\begin{array}{l}\text { Korean Association of Sport and } \\
\text { Entertainment Law }\end{array}$ \\
\hline & The Process and Prospect of Elite Sport Policies according to Political Transitions in Korea & Kim, D. (2000) & $\begin{array}{l}\text { Korean Society for the Philosophy } \\
\text { of Sport, Dance \& Martial Arts }\end{array}$ \\
\hline & $\begin{array}{l}\text { A Comparison of Nationalistic Sports Policies between the Third and Fifth Republic Governments in } \\
\text { Korea }\end{array}$ & Lee, O., Ju, D., Kim, D. (2001) & $\begin{array}{l}\text { Korean Society for the Philosophy } \\
\text { of Sport, Dance \& Martial Arts }\end{array}$ \\
\hline & $\begin{array}{l}\text { A Study on the Physical Education Policy and Expansion of the Third Government of the Republic of } \\
\text { Korea }\end{array}$ & Lee, J. (1997) & Seoul National University \\
\hline & $\begin{array}{l}\text { Research Positive Points and Negative Points on Physical Education Policy in 5th Republic of Korea - } \\
\text { Lay Elite Sports Upbring on }\end{array}$ & Kim, T., Park, I. (2004) & Korean Society of Sport Policy \\
\hline & Direction of Physical Education in Schools for the Promotion of Elite Sports & Park, J. (2019) & Korean Society of Sport Policy \\
\hline & A Social Historical Study on the Policy Orientation of Elite Sport in Korea during the 1960's-1970's & Lee, J. (2005) & KAHPERD \\
\hline & $\begin{array}{c}\text { A Study on the reactivating Plans of Promoting Project on the Basic Sports Gifted Children in the } \\
\text { Elementary School }\end{array}$ & $\begin{array}{l}\text { Jung, Y., Choi, M., Lee, Y. } \\
\text { (2016) }\end{array}$ & Korean Society of Sport Policy \\
\hline
\end{tabular}


Table 3. Final Selected Previous Research (Korean) Continue

\begin{tabular}{|c|c|c|c|}
\hline & Research Title & Author (Year) & Publish Institute \\
\hline \multirow{19}{*}{$\begin{array}{c}\text { Korean } \\
(46)\end{array}$} & $\begin{array}{c}\text { 경기력 G7시대 엘리트 스포츠 경기력 육성방향: 권역별 스포츠영재 발굴, 육성 현황 및 미래 방향 } \\
\text { (Korean Title Only) }\end{array}$ & Choi, U. (2011) & Korean Institute of Sport Science \\
\hline & 경기력 G7시대 엘리트 스포츠 경기력 육성방향. 스포츠선진국을 향한 엘리트체육 육성방안 & Choi, K. (2011) & Korean Institute of Sport Science \\
\hline & $\begin{array}{l}\text { Protection of Sport Rights and Legal Change for the National Sport Promotion ; Structure for the } \\
\text { Enactment of Fundamental Law of Sport in Korea }\end{array}$ & Yeon, K. (2008) & $\begin{array}{l}\text { Korean Association of Sport and } \\
\text { Entertainment Law }\end{array}$ \\
\hline & 엘리트스포츠 육성, 체육 정책의 핵심이 되어야(Korean Title Only) & Kim, J. (2003) & Korean Institute of Sport Science \\
\hline & 엘리트체육 육성을 위한 체육단체의 기능과 역할 (Korean Title Only) & Yu, U. (2005) & Korean Institute of Sport Science \\
\hline & A Study on the Development of School Elite Sports & Kim, D. (2017) & Korean Society of Sport Policy \\
\hline & Reality and Task of Korean Sports Culture (3): Operation Mechanism and Pointing Spot of Elite Sports & Kim, Y. (2015) & $\begin{array}{l}\text { Korean Society for the Philosophy } \\
\text { of Sport, Dance \& Martial Arts }\end{array}$ \\
\hline & 한국 엘리트 스포츠 정책의 사회 철학적 진단과 발전과제 (Korean Title Only) & Kim, D. (2003) & Korean Society of Sport Policy \\
\hline & The Products and Prospectis of Korean Elite Sports & Kang, C., Lee, J. (2004) & $\begin{array}{l}\text { Korean Society for the Philosophy } \\
\text { of Sport, Dance \& Martial Arts }\end{array}$ \\
\hline & A legal study on the special case of military service in athletes & Son, S. (2011) & Korean Society of Sport Policy \\
\hline & Elite Sport in South Korean Society -Consequences of the 1988 Seoul Olympic Games- & Cho, J. (2013) & Korean Society of Sport Policy \\
\hline & Processing and Prospect of Korean Sport Policies & Jung, J., Kim, D. (2003) & KAHPERD \\
\hline & 효율적인 엘리트 체육 정책 방안에 관한 연구 (Korean Title Only) & Lee, B., Oh, J., Kim, J. (1999) & Yong In University \\
\hline & $\begin{array}{l}\text { Policy Suggestions for Athlete's Career Development and Transition: A Case of German Support } \\
\text { Program for Athlete's Dual Career }\end{array}$ & Kim, K. (2014) & Korean Academy of Kinesiology \\
\hline & The Critical Consideration of the Career Support Project for Retired Athletes & Choi., M. (2016) & KAHPERD \\
\hline & Lee Administration's Vision and Challenges for Elite Sport & Kim, D., Park, J. (2008) & Korean Society of Sport Policy \\
\hline & An study on effectiveness evaluation of elite sports policy & Lee, Y. (2013) & Korean Society of Sport Policy \\
\hline & 참여정부 체육정책의 비전과 과제 - 참여정부 체육정책의 비전과 과제 (Korean Title Only) & Kim, T. (2004) & KOREA SPORT SOCIETY \\
\hline & Policy Keynotes for the Integration of Sport Organizations & Park, J. (2016a) & Korean Society of Sport Policy \\
\hline
\end{tabular}

핵심단어는 'Korea's Elite sport policy'와 'Korea's talent identification development'를 적용하였다. 국문 선행 연구 분석 시 설정한 핵심단어와 동일한 논리와 맥 락으로 위 단어들을 선정하였다.

SPORTDiscuss을 통해 검색한 결과를 살펴보면 'Korea's elite sport policy'는 중복 논문 10개를 제외하고 604개, 'Korea's talent identification development'는 중복된 논문 2 개를 제외하고 302 개로 총 906 개의 논문이 검색되었다. 이를 통해 중복 122 개를 제외한 784 개의 기 존 연구가 분석대상으로 선정되었다. Scopus의 경우는 'Korea's elite sport policy'는 중복 제외 310개가 검색되 었고 'Korea's talent identification development'는 329 개가 검색되었다. 두 개의 검색결과 629 개 중 중복되 는 논문 9 개를 제외한 결과 620 개 기존 연구가 대상으로
선정되었다.

선정한 분석대상을 다시 각기둥 흐름표 (prisma flow cart)를 활용한 문헌 선정 과정을 거쳐 분석할 자료를 선 별하였다. 앞선 검색결과를 통합하여 첫 번째 단계로서 총 1,404 개의 논문 중 중복되는 논문 21 개를 배제하고, 제목 수준에서 연구문제와 관계가 적은 논문을 배제했다. 그 결과 137 개의 논문이 선정되었다.

두 번째 단계에서는 1 차에서 배제되지 않은 137 개의 논문을 초록을 기준으로 연구 결과 및 결론에서 제시하고 있는 내용이 동 연구의 목적과의 부합여부를 살펴보았다. 먼저, 주제가 전문체육 정책이 아닌 운동학적 분석, 선수 훈련, 생활 체육 등에 대한 내용을 담고 있는 논문을 배제 했다. 그 후 해외 전문체육 정책, 등에 대한 내용이 배제 되었다. 그 결과 34 개의 논문을 선정했다. 
Table 4. Final Selected Previous Research (English)

\begin{tabular}{|c|c|c|c|}
\hline & Research Title & Author & Publish Institute \\
\hline \multirow{7}{*}{$\begin{array}{l}\text { English } \\
\text { (7) }\end{array}$} & $\begin{array}{l}\text { Applying a Western-based policy community framework to the } \\
\text { analysis of South Korean elite sport policy: The role of } \\
\text { businesses and armed forces. International journal of sport policy } \\
\text { and politics }\end{array}$ & Hong (2012) & $\begin{array}{l}\text { International Journal of Sport } \\
\text { Policy }\end{array}$ \\
\hline & $\begin{array}{c}\text { THE PROTECTION OF SPORTS FUNDAMENTAL RIGHTS } \\
\text { AND LEGISLATION OF THE BASIC SPORTS LAW IN } \\
\text { KOREA }\end{array}$ & Yeun (2016) & $\begin{array}{l}\text { International Sports Law } \\
\text { Review Pandektis }\end{array}$ \\
\hline & Sports Talent Identification and Selection in Korea & Кo (2014) & $\begin{array}{l}\text { International Journal of } \\
\text { Applied Sports Sciences }\end{array}$ \\
\hline & $\begin{array}{l}\text { Sport, politics and reunification-a comparative analysis of Korea } \\
\text { and Germany }\end{array}$ & $\begin{array}{l}\text { Merkel \& Udo } \\
\text { (2009) }\end{array}$ & $\begin{array}{l}\text { International Journal of the } \\
\text { History of Sport }\end{array}$ \\
\hline & $\begin{array}{c}\text { Exploring the truth: A critical approach to the success of Korean } \\
\text { elite sport }\end{array}$ & $\begin{array}{c}\text { Park, Lim, \& } \\
\text { Bretherton, (2012) }\end{array}$ & $\begin{array}{c}\text { Journal of Sport and Social } \\
\text { Issues } \\
\end{array}$ \\
\hline & $\begin{array}{l}\text { The development of sport policy and management in South } \\
\text { Korea }\end{array}$ & Won, \& Hong (2015) & $\begin{array}{l}\text { International Journal of Sport } \\
\text { Policy }\end{array}$ \\
\hline & $\begin{array}{l}\text { A chronological review of the development of elite sport policy } \\
\text { in South Korea }\end{array}$ & Park, \&Lim (2015) & $\begin{array}{l}\text { Asia Pacific Journal of Sport } \\
\text { and Social Science }\end{array}$ \\
\hline
\end{tabular}

세 번째 단계에서는, 선정된 34개의 논문을 연구목적 을 기준으로 질적평가를 실시했다. 논문의 분석의 틀인 전문체육 정책 의제 설정과정에 영향을 미친 문제, 정책, 정치의 흐름을 기준으로 질적평가를 진행한 결과 〈Table $4>$ 와 같이 최종적으로 7 개의 논문을 분석대상으로 선정 했다.

\section{자료분석방법}

자료검증을 위해 동료검증(peer debriefing)을 실시했 다. 스포츠사회학과 스포츠경영 전공자 3명 간 상호작용 을 통해 분석과정, 체계, 결과에 대한 피드백을 받았다.

수집된 자료 분석을 위해 내용분석방법과 범주화 및 항목화 방법을 활용하였다. 언론기사 문헌조사, 심층면 담, 기존연구 문헌조사 방법을 통해 최종적으로 수집된 분석 자료를 바탕으로 내용분석을 실시하여 기초요인을 도출하고 3 단계 범주화와 항목화를 통해 최종결과를 도 출하였다.

먼저 내용분석을 실시했다. 3 명의 코더는 개별적으로 최종적으로 선별된 분석자료를 바탕으로 구성요인를 도 출하였다. 도출된 결과를 기반으로 통합논의를 통하여 도 출된 구성요인들 중 중복 혹은 유사한 의미를 지니고 있 는 요인을 합치고 불필요하게 도출된 요인을 삭제하여 최 종적인 결과를 얻었다. 이를 바탕으로 3 단계의 범주화 및
항목화를 실시하였다.

첫 번째 단계에서는 개별적으로 각 영역별로 도출된 구성요소를 대상으로 범주화를 실시하여 결과를 도출하 였다. 두 번째 단계에서는 상호검증을 진행하였으며 다른 코더가 도출한 결과를 바탕으로 개별 진행하여 얻은 결과 를 비교 검토하여 수정하는 과정을 진행하였다. 세 번째 단계에서는 통합논의를 진행하여 최종적인 범주화를 진 행하고 각 범주에 대한 항목화를 진행하여 최종결과를 도 출하였다.

\section{연구결과}

앞서 언급한 세 가지 자료 수집 방법을 통해 구성요인, 세부요인, 주요요인 순으로 범주화와 항목화 과정을 결처 결과를 도출하였다 도출된 결과들은 선행연구에서 제시 한 정책문제흐름, 정책대안흐름, 정치흐름(Kingdon, 1984)에서 크게 벗어나지 않음을 알 수 있었다.

\section{정책문제흐름}

다중흐름모형 중 정책문제흐름 관점에서 국제스포츠 대회 성적, 국제스포츠대회 참가 및 개최, 엘리트선수수 급, 선수지원체계, 종목지원체계, 학생학습권/학생인권/ 
Table 5. Policy Problem Stream Perspective Results

\begin{tabular}{|c|c|c|}
\hline Component Factor_Korean & Factor & Source \\
\hline 비인기 종목 등 국제경쟁력 하향 & \multirow{4}{*}{$\begin{array}{c}\text { International Sports Event } \\
\text { Result }\end{array}$} & R, I \\
\hline 경기력 저하 & & $\mathrm{R}, \mathrm{I}$ \\
\hline 1976년 몬트리올 올림픽 최초 금메달 획득 & & $\mathrm{R}$ \\
\hline LA올림픽 이후 종합성적 10 위권 & & $\mathrm{R}$ \\
\hline 동경올림픽 및 각종 국제스포츠 이벤트를 대비한 국민체육진흥법 해석 및 운용 & \multirow{5}{*}{$\begin{array}{l}\text { Hosting International } \\
\text { Sports Event }\end{array}$} & $\mathrm{R}$ \\
\hline 88년 올림픽 유치및 우수한 성적에 대한 필요성 증대 & & $\mathrm{R}$ \\
\hline 한일월드컵 개최 & & $\mathrm{R}$ \\
\hline 올림픽 유치 노력 시작(1967) & & $\mathrm{R}$ \\
\hline 1948년 런던 올림픽 참가 & & $\mathrm{R}$ \\
\hline 생활체육으로부터 엘리트 선수공급이 거의 불가능한 상황 & \multirow{17}{*}{$\begin{array}{l}\text { Elite Sports Athletic } \\
\text { Recruiting }\end{array}$} & $\mathrm{R}, \mathrm{I}$ \\
\hline 일부 인기 종목으로의 스포츠 인구 편중 & & $\mathrm{R}, \mathrm{I}$ \\
\hline 대표선수에 비해 꿈나무 선수 육성 소홀 & & $\mathrm{R}, \mathrm{I}$ \\
\hline 학원 엘리트 스포츠에 전적으로 의존하여 신인 선수 발굴 양성 수급 어려움 & & $\mathrm{R}$ \\
\hline 초등학교 과정에서 선수자원 확보 어려움 & & $\mathrm{R}$ \\
\hline 꿈나무 선수 감소율 매우 높음 & & $\mathrm{R}$ \\
\hline 학생 스포츠 인구 급격한 감소에 따른 엘리트 스포츠 저변 붕괴 & & $\mathrm{R}, \mathrm{I}$ \\
\hline 인기종목 편중현상 & & $\mathrm{R}, \mathrm{I}$ \\
\hline 선수층 취약 & & $\mathrm{R}, \mathrm{I}$ \\
\hline 육성 선수 규모와 종목이 역피라미드 형태 & & R, I \\
\hline $\begin{array}{c}\text { 80년대 이후 체육정책이 엘리트 스포츠 위주로 진행되어 학교 체육 극도로 위축시켜 } \\
\text { 엘리트 스포츠 기반 약화 }\end{array}$ & & $\mathrm{R}$ \\
\hline 학교체육과 생활체육 연계 부족 & & $\mathrm{R}, \mathrm{I}$ \\
\hline 종목별 후보선수 수는 몇 개 종목 제외하고 전체적으로 감소 추세 & & $\mathrm{R}$ \\
\hline 1972년 소년체전을 전국체전으로부터 분리 & & $\mathrm{R}$ \\
\hline 일반스포츠 클 럽 통해 선수 수급 채널 부재 & & $\mathrm{I}$ \\
\hline 여자 선수 수급을 위한 대책 필요 & & $\mathrm{I}$ \\
\hline 해외 교포 선수 국내 유도에 어려움 & & I \\
\hline 유소년을 육성을 위한 장기적 체계적 프로그램 부재 & \multirow{14}{*}{$\begin{array}{l}\text { Athletic and Sports } \\
\text { Category Supporting } \\
\text { System }\end{array}$} & I \\
\hline 각 단계 선수들을 관리 할 수 있는 DB 또는 노트의 부재 & & I \\
\hline 스포츠 영재 발굴 관련 센터별 공통성 및 차별성 위한 세부지침 부족 & & $\mathrm{R}$ \\
\hline 영재프로그램 후 지속적 자료 추적 또는 추가 프로그램 부족 & & $\mathrm{R}$ \\
\hline 꿈나무와 후보 사이에 공백 존재 & & $\mathrm{R}, \mathrm{I}$ \\
\hline 전문 심판 양성 필요 & & I \\
\hline 전문 또는 해외 우수지도자 수급 필요 & & I \\
\hline 지도자 자질 향상을 위한 기준 수립 및 강화 필요 & & $\mathrm{I}$ \\
\hline 각 단계별 지도자 연수의 부재 & & I \\
\hline 장비 매니저 수급 필요 & & I \\
\hline 전문 행정 인력 충원 필요 & & I \\
\hline 훈련이 1회성이나 훈련기간이 짧음 & & I \\
\hline 해외전지훈련 또는 대회참여 기회 확대 필요 & & $\mathrm{I}$ \\
\hline 대표 선수를 제외하면 상시 합동훈련체제가 아니므로 과학적 지원 미미 & & $\mathrm{R}, \mathrm{I}$ \\
\hline 2013 학교 체육 진흥법(학생 선수 인권/학습권) & \multirow{7}{*}{$\begin{array}{l}\text { Student Study Right/ } \\
\text { Student Human Right/ } \\
\text { Sports Academy }\end{array}$} & $\mathrm{R}$ \\
\hline 학생들의 교육기회 희생(단기 경기 성과를 위해) & & $\mathrm{R}$ \\
\hline 금메달 지상주의로 인한 학생 선수들의 수업 불참 만연 & & $\mathrm{R}, \mathrm{I}$ \\
\hline 신체적 기능만이 강조되면서 일반 교과교육과 훈련 간 비조화 & & $\mathrm{R}, \mathrm{I}$ \\
\hline 스포츠 영재교육을 통해 경기력만 추구하는 기능적 엘리트 선수 육성 & & $\mathrm{R}, \mathrm{I}$ \\
\hline 엘리트체육의 바탕인 학교체육의 활성화 & & $\mathrm{I}$ \\
\hline 다양한 종목에 노출될 기회 부족 & & $\mathrm{R}, \mathrm{I}$ \\
\hline
\end{tabular}

※ R: Previous Reseearch, P: Press, I: Depth Interview 
Table 5. Policy Problem Stream Perspective Results (Continue)

\begin{tabular}{|c|c|c|}
\hline Component Factor_Korean & Factor & Source \\
\hline 스포츠 관련 다양한 집단의 이해가 고려되지 못한 불합리한 체육 정책 의사결정 과정 & \multirow{7}{*}{ Policy Reality } & R, I \\
\hline 탑다운식 스포츠 정책 결정 & & $\mathrm{R}$ \\
\hline 체육 정책 결정에서의 민주적 참여 부족 & & $\mathrm{R}$ \\
\hline 초기 엘리트 스포츠 운영모델이 전문체육인이 아닌 국가와 기업의 시선과 방식으로 재단 & & $\mathrm{R}$ \\
\hline 국민, 선수, 지도자, 교사 등 현장의 목소리를 반영할 수 있는 정책 수립 필요 & & $\mathrm{P}$ \\
\hline 스포츠 정책 수립 시 광범위한 참여를 통한 민의 반영 부족 & & $\mathrm{R}$ \\
\hline 한국적 상황에 부합하는 체육모델 부재 & & $\mathrm{R}$ \\
\hline $\begin{array}{c}\text { 체육과학연구원의 역할 확대, 4년마다의 대회에만 매달리는 것이 아니라 국민체육진흥도 연구 } \\
\text { 필요 }\end{array}$ & \multirow{3}{*}{$\begin{array}{c}\text { Sport } \\
\text { Expert/Institute } \\
\text { Capability }\end{array}$} & $\mathrm{P}$ \\
\hline 체육전문가들의 체육정책프로그램 담당 필요 & & $\mathrm{P}$ \\
\hline 체육회의 국민생활체육협의회의 통합을 통해 본질적으로 업무 중복 해소 필요 & & $\mathrm{P}, \mathrm{I}$ \\
\hline 엘리트 스포츠는 국가목적 달성을 위한 저비용 고효율 정책 전략으로 인식 & \multirow{16}{*}{$\begin{array}{l}\text { Perception of } \\
\text { Elite Sport } \\
\text { Origin }\end{array}$} & $\mathrm{R}$ \\
\hline 엘리트 스포츠가 정치적 전략으로 동원 & & $\mathrm{R}$ \\
\hline $\begin{array}{c}\text { 엘리트 스포츠패러다임은 국위선양, 국민통합, 체제우월성입증을 위한 업적위주의 정책 } \\
\text { 매커늠으로 작동 }\end{array}$ & & $\mathrm{R}$ \\
\hline $\begin{array}{c}\text { 5.16군사혁명 이후 국민체육진흥을 통해 국민통합원동력을 마련, 국가발전기본은 } \\
\text { 엘리트스포츠임을 강조 }\end{array}$ & & $\mathrm{R}$ \\
\hline 생활체육부터 엘리트체육까지 유기적으로 연결되는 정책 뒷받침, 국민의 자발적 참여 필요 & & $\mathrm{P}$ \\
\hline $\begin{array}{c}\text { 선수양성을 바라보는 팬들의 의식의 변화, 국가대표 중심 정부태도 변화, 운동부 중심 선수양성 } \\
\text { 조 탈피 }\end{array}$ & & $\mathrm{P}$ \\
\hline 엘리트 스포츠는 메달지상주의와 직결된다는 인식 & & $\mathrm{R}$ \\
\hline 승리 제일주의가 지배하는 스포츠문화 이데올로기 & & $\mathrm{R}$ \\
\hline 체육계 성적 지상주의, 엘리트 체육 위주의 육성 방식에 대한 재검토 필요 & & $\mathrm{P}$ \\
\hline IMF 이후 스포츠는 구조조정 0순위 & & $\mathrm{R}$ \\
\hline 100개 실업팀 해체 & & $\mathrm{R}$ \\
\hline IMF이후 98년 3월 19개 종목 40개 실업팀 해체 & & $\mathrm{R}$ \\
\hline 한보 씨름단 육상팀 해체(1997) & & $\mathrm{R}$ \\
\hline 학생선수에 대한 명확한 정의와 체육정책의 명확한 목적성 확보 & & $\mathrm{P}$ \\
\hline 학교스포츠부 및 기업 스포츠팀 수가 급격히 감소 & & $\mathrm{R}, \mathrm{I}$ \\
\hline 학교체육을 엘리트 체육 육성장으로서의 활용 & & $\mathrm{P}$ \\
\hline
\end{tabular}

※ R: Previous Research, P: Press, I: Depth Interview

학원스포츠, 정책 현실성, 스포츠 전문가/기관 역량, 전 문체육 본질 인식과 같은 요인이 도출되었다. 도출 결과 는 〈Table 5〉을 통해 제시하였다.

국제스포츠대회 성적 요인의 경우 선행연구에서는 한 국은 1948년 런던 올림픽 참가 이후, 1976년 몬트리울 올림픽에서의 최초 금메달 획득, 1984 년 LA 올림픽 이 후 종합 성적 10 위권을 유지한 부분을 제시하였다. 이후 경기력 저하, 비인기 종목 등의 국제 경쟁력이 떨어지는 현상들은 2010년 청소년 대표 정책이 정책 의제로 설정 될 수 있었다는 부분이 강조되었다. 또한 상비군 재설치 와 관련된 중복 의견이 심층면담을 통해 8회 가량 도출되 었다.
"후보팀과 대표팀과의 실력차이가 많이 나고 있습니다. 서 로 파트너로서 훈련하기가 쉽지 않아 이상적 훈련이 안되고 있습니다. 중간 위치에 상비군이 필요하다고 생각됩니다."

국제스포츠대회 참가 및 개최 요인을 살펴보면 선행연 구에서는 1964년 동경 올림픽 이후 각종 국제 스포츠 대 회를 대비하여 국민체육진흥법을 제정하고 이를 운용해온 방식은 전문체육 정책 의제 설정에 있어 대회 참가가 영향 을 미침을 증명하였다. 또한 1967년부터 나타난 한국 정 부의 올림픽 유치 노력에서 시작된 정부의 국제 스포츠 대 회 유치에 대한 의지는 1988년 서울 올림픽, 2002년 한일 월드컵, 2018 평창 동계올림픽에 이르기까지 전문체육 정 책 의제화에 영향을 미친 것으로 나타났다.

전문체육선수 수급 요인의 경우 정부가 1972년 전국 
체전으로부터 소년체전을 분리시켜 전문체육선수 수급 및 양성에 노력하고 1980 년대 이후 체육 정책의 주된 내 용은 전문체육에 대한 것이었다고 제시하였다. 하지만 이 로 인해 학교체육이 위축되는 현상이 나타나 전문체육의 저변을 붕괴하는 부메랑 효과를 야기한 것으로 설명되었 다. 국가대표선수에 비해 꿈나무선수 육성에 소홀하여 자 연히 꿈나무선수 감소율은 매우 높아졌고 초등학교 과정 에서의 선수 자원 확보가 어려워졌을 뿐 아니라 인기 종 목 편중현상 등이 일어났다. 심층면담에서 3 인의 연구참 여자들은 선수층이 취약하고 선수가 부족함을 언급했다.

"꿈나무는 큰 의미가 없습니다. 어차피 대회도 없고 대회에 참가할 선수들도 없고요"

더 나아가 전문체육선수 수급 측면에서 선행연구는 학 교체육과 생활체육의 연계 부족은 생활체육으로부터 전 문체육선수를 공급받는 것이 거의 불가능한 상황을 양산 했다고 설명하였다. 종목별 국가대표후보선수 수는 몇 개 종목을 제외하면 전반적으로 감소하는 추세이며, 여자선 수 부족 및 해외교포 선수 국내 유도의 어려움은 한국의 전문체육 정책 의제 설정에 영향을 미친 것으로 제시하였 다. 심층면담 내용 역시 관련된 정보를 제시하고 있다.

"다들 너무 늦게 시작하고 이로 인해 기술이 떨어져서 어려 움이 있습니다. 조금 일찍 전문적으로 선수를 길어낼 수 있 는 토양이 필요합니다."

선수 및 종목 지원 체계 요인의 경우는 선행연구에서 선수 지원 체계와 관련하여 전문체육선수 체계적 관리, 지원인력, 훈련제도 등이 의제설정과정에 영향을 미친 것 으로 나타났다. 또한 종목 지원 체계의 경우 청소년 사업 종목과 후보 종목의 불일치, 메달 획득 가능성 높은 종목 에 대한 집중투자, 동계/하계 종목 간 간극, 비인기 종목 에 대한 한시적 지원 등은 한국 전문체육 정책 의제설정 에 영향을 미친 것으로 도출되었다. 심층면담에서는 다음 과 같은 내용이 도출되었다. 구체적으로 선수관리 체계 미흡에 대한 의견을 5 인의 연구 참여자가 제시하였으며, 전문적 지도자 수급이 필요하다는 의견은 7 인의 연구 참 여자가 제시했다. 또한 선수 지도자 자질 향상 필요성에 대한 언급은 9 차례 중복의견으로 도출되었으며, 지도자
연수 강화에 대한 내용은 3 회, 전문 행정 인력에 대한 필 요성 역시 3 회 중복 언급되었다. 이와 함께 훈련 기간의 조정과 해외전지훈련 및 해외대회 참여 확대에 대한 내용 이 각각 6 차례, 2 차례 중복 도출되었다.

"개인기록 간의 연결성을 확보하기 어렵고 이러한 이유로 단계별, 수준별 학습지도에도 어려움이 있습니다."

"지금 현재는 최상의 기량을 갖추고 있지만 국제대회에 지 속적으로 참여할 수 있는 기회가 감소하고 대회 경험을 얻지 못한다면 현재의 기량을 유지하기가 힘들 수 있다."

"지도자를 선발하고 교육할 수 있는 체계 구축이 필요합니 다. 또한 각 단계별 지도자 요건에 맞는 급수 조정이 필요합 니다."

"행정인력이 절실히 필요하며 훈련보다는 행정처리에 소요 되는 시간이 너무 많습니다."

학생학습권/학생인권/학원스포츠 요인과 관련해서는 선행연구의 경우 한국 전문체육의 메달 지상주의로 인해 학생들의 교육 기회를 희생해가며 학생 선수들의 수업 불 참이 당연시 되는 문화가 존재해 온 것으로 제시하였다. 더하여 신체적 기능만이 강조되며 일반 교과 교육과 훈련 간 조화를 이루지 못하여 스포츠 영재 교육을 통해 경기 력만 향상된, 성적만을 향해 달려가는 절름발이 전문체육 선수를 양산된 것으로 설명하였다. 더욱이 학교 체육은 다양한 종목에 노출될 기회를 주지 못하여 이러한 현상들 이 정책 의제 설정에 영향을 미친 것으로 나타났다. 심층 면담에서는 다음과 같은 정보가 제시되었다.

"수업일수 때문에 훈련일정을 수립하는데 어려움이 있으며 훈련극대화에 어려움이 있습니다. 지역별 교육프로그램이 필요하다고 생각합니다."

정책 현실성 요인의 경우 선행연구에서는 스포츠 분야 의 다양한 이해집단의 의견이 반영되지 못한 불합리한 체 육정책 의사결정과정이 주요한 영향을 미친 것으로 나타 났다. 언론기사에서는 정권에 따라 정도의 차이는 있겠지 만 대개 하향식으로 이루어지는 정책 결정 과정으로 인해 국민, 선수, 지도자, 교사 등 현장의 목소리를 반영하지 못하는 것으로 나타났다. 궁극적으로 이로 인해 한국적 
Table 6. Policy Alternative Stream Perspective Results

\begin{tabular}{|c|c|c|}
\hline Component Factor_Korean & Factor & Source \\
\hline 국민체육진흥법 및 정부조직법 개정을 통해 체육부 발족 & \multirow{18}{*}{$\begin{array}{c}\text { Sports Related } \\
\text { Administrative } \\
\text { Organization Restructure }\end{array}$} & $\mathrm{R}$ \\
\hline 체육 담당 행정기구 대폭 확대 & & $\mathrm{R}$ \\
\hline 정권 교체 후 체육국이 체육 국제국으로 개편 & & $\mathrm{R}$ \\
\hline 엘리트 체육의 체계적 육성을 위한 체육부 신설 & & $\mathrm{R}$ \\
\hline 이명박 정부는 문화체육관광부로 명칭 변경 & & $\mathrm{R}$ \\
\hline 김대중 정부의 체육행정 조직 축소로 문화체육부가 문화관광부로 변경 & & $\mathrm{R}$ \\
\hline $\begin{array}{c}\text { 전두환 정부 체계적 엘리트 스포츠 육성을 위한 체육부 신설 } \\
\text { (체육 진흥국, 체육 과학국, 국제 체육국 신설 1982.3.20) }\end{array}$ & & $\mathrm{R}$ \\
\hline 작은 정부 구현에 따른 김영삼 정부의 문화부와 체육청소년부의 문화체육부 개편 & & $\mathrm{R}$ \\
\hline 스포츠행정 관련 업무가 여러 부처에 분산되어 효율적 정책 집행 어려움 & & $\mathrm{R}$ \\
\hline 미군정 기간 동안 체육담당 부서의 찾은 개편 & & $\mathrm{R}$ \\
\hline 1920년 조선체육회 출범 & & $\mathrm{R}$ \\
\hline 1948년 대한체육회로 개칭. 83년 법정법인 체육단체로 출범 & & $\mathrm{R}$ \\
\hline 유사한 기능의 조직의 통폐합을 통한 효율적 정비 & & $\mathrm{P}$ \\
\hline 정부의 지나친 간섭으로 인한 쇼윈도식 정책의 탈피 필요 & & $\mathrm{P}, \mathrm{I}$ \\
\hline 조직의 실질적인 권한부여와 업무효율 증대를 통한 실행가능성 확보 & & $\mathrm{P}$ \\
\hline 체육행정 통합을 통한 역량 집중 필요 & & $\mathrm{P}, \mathrm{I}$ \\
\hline 학교체육 정책 등 총괄 업무 부서 설립 필요 & & $\mathrm{P}$ \\
\hline 주체 기관이 분리될 경우 효율성이 떨어질 수 있음 & & $\mathrm{P}, \mathrm{I}$ \\
\hline 2015년까지 실시한 초등 기초영재 육성사업 폐지 & \multirow{5}{*}{$\begin{array}{l}\text { Supporting Policy of Elite } \\
\text { Athletic Promoting } \\
\text { Restructure }\end{array}$} & $\mathrm{R}$ \\
\hline 우수영재육성사업만 2016년부터 추진 & & $\mathrm{R}$ \\
\hline 청소년 대표선수 정책 신설(2010) & & $\mathrm{R}$ \\
\hline 체육영재 육성사업 시행(2009) & & $\mathrm{R}$ \\
\hline 우수영재 육성사업 시행(2015) & & $\mathrm{R}$ \\
\hline 호돌이 계획(1989) 등장 & \multirow{5}{*}{$\begin{array}{c}\text { Parent Policy of Elite } \\
\text { Athletic Promoting Policy }\end{array}$} & $\mathrm{R}$ \\
\hline 이분형 스포츠 지원 정책 등장(대표 및 후보선수 지원 vs 개인형 생활스포츠) & & $\mathrm{R}, \mathrm{I}$ \\
\hline 김영삼 정부의 5개년 계획 (sport for all, 1993-1997) & & $\mathrm{R}$ \\
\hline 김대중 정부의 2차 5개년 계획(1998-2002) & & $\mathrm{R}$ \\
\hline 일부종목, 일부선수에 대한 의존, 올림픽에 대한 치중보다는 중장기적 전략 마련이 시급 & & $\mathrm{P}, \mathrm{I}$ \\
\hline 1962년 국민체육진흥법 제정 배경은 정치사회경제 불안상태 문화적 통제 필요성 & \multirow{5}{*}{$\begin{array}{l}\text { Parent Institution of Elite } \\
\text { Athletic Promoting Law }\end{array}$} & $\mathrm{R}$ \\
\hline 국민 참여 체육 정책 수립, 집행, 민간 자율성 강화를 위한 지방이양 & & $\mathrm{R}$ \\
\hline 국제대회 준비 및 엘리트 스포츠 육성 위한 5공화국 국민체육진흥법 전문개정 & & $\mathrm{R}$ \\
\hline 엘리트 스포츠 육성을 위한 3,4공화국 국민체육진흥법 3차례 개정 & & $\mathrm{R}$ \\
\hline 김대중 정부는 월드컵 개최를 위한 특별법화 된 성격으로 국민체육진흥법활용 & & $\mathrm{R}$ \\
\hline 1963년 (스포츠 선수/국가대표) 연금제도 도입 & \multirow{4}{*}{$\begin{array}{l}\text { Incentive Institution for } \\
\text { Elite Athletic }\end{array}$} & $\mathrm{R}$ \\
\hline 60-70년대 엘리트 스포츠 중점 육성 위해 엘리트 선수들의 동기유발 위한 특별법 시행 & & $\mathrm{R}$ \\
\hline 엘리트 선수들에 대한 병역특례법, 연금제도, 특기자 제도 신설 & & $\mathrm{R}$ \\
\hline 우수선수 보상제도 등장 & & $\mathrm{R}$ \\
\hline 1982년 상무제도 신설 & \multirow{8}{*}{$\begin{array}{l}\text { Supporting Institution for } \\
\text { Elite Athletic }\end{array}$} & $\mathrm{R}$ \\
\hline 스포츠 과학 연구소 개설 & & $\mathrm{R}$ \\
\hline 접근성 및 전문성을 갖춘 시설 미비 & & $\mathrm{I}$ \\
\hline 공립 선수 훈련원인 태능 선수촌 및 체육과학연구원 설립 & & $\mathrm{R}$ \\
\hline 각종 체육 계열학교 설립 & & $\mathrm{R}$ \\
\hline 우수선수 발굴센터 설치 & & $\mathrm{R}$ \\
\hline 국가대표 훈련 일수 증대 & & $\mathrm{R}$ \\
\hline 경기력 향상 특별 지원 & & $\mathrm{R}$ \\
\hline
\end{tabular}

※ R: Previous Research, P: Press, I: Depth Interview 
Table 6. Policy Alternative Stream Perspective Results (Continue)

\begin{tabular}{|c|c|c|}
\hline Component Factor_Korean & Factor & Source \\
\hline 엘리트 선수 각 단계별 특성화된 프로그램 부재 & \multirow{6}{*}{$\begin{array}{c}\text { Value of Policy } \\
\text { Community for } \\
\text { Sports Category } \\
\text { Feature }\end{array}$} & I, R \\
\hline 선발 주체 및 기준이 각 단계별 및 종목별로 상이 & & I \\
\hline 선발 선수 연령 기준 혼선(학년/나이) & & I \\
\hline 각 단계별 목표의 불명확성 & & I \\
\hline 각 단계별 또는 종목별 지도자 선발 기준안 부재 & & I \\
\hline $\begin{array}{c}\text { 인기 종목은 리그를 통해 활성화, 비인기종목은 국가가 어릴 때 선발부터 은퇴 후 삶까지 } \\
\text { 필요 }\end{array}$ & & $\mathrm{P}$ \\
\hline 각 단계별 사업예산 적정성 평가 필요 & \multirow{5}{*}{$\begin{array}{l}\text { Value of Policy } \\
\text { Community for } \\
\text { Sports Category } \\
\text { Fairness }\end{array}$} & I, R \\
\hline 종목수가 각 단계별로 상이 & & I \\
\hline 과학적 훈련장비 확충 예산 마련 필요 & & I \\
\hline 수익금 배분률 조정을 통해 예산의 일관성 확보 & & I \\
\hline 각 단계별 사업예산 적정성 평가 필요 & & $\mathrm{R}, \mathrm{I}$ \\
\hline 국민체육기금의 스포츠 부문으로의 배분 확대 & \multirow{9}{*}{ Budget } & $\mathrm{P}$ \\
\hline 예산 집행의 효율성 확보 & & P, I \\
\hline 체육기금의 안정적인 확보 여부 & & $\mathrm{P}, \mathrm{I}$ \\
\hline 체육재정 부족 & & R, I \\
\hline 수익금 배분률 조정을 통해 예산의 일관성 확보 & & R, I \\
\hline 엘리트 선수 지원 관련 측정 시스템 미흡 예산 부족 & & $\mathrm{R}$ \\
\hline 정부는 엘리트스포츠 정책을 시행하지만 부족한 예산은 기업에서 충당 & & $\mathrm{R}$ \\
\hline 경기단체들의 낮은 재정 자립도 & & $\mathrm{R}, \mathrm{I}$ \\
\hline 지원금의 투명한 집행 & & $\mathrm{P}, \mathrm{I}$ \\
\hline 올림픽 유치 계획 시작 (1967) & \multirow{2}{*}{$\begin{array}{c}\text { International Sports } \\
\text { Event Hosting Policy }\end{array}$} & $\mathrm{R}$ \\
\hline 국제 대회 창설 및 유치 필요성 강조하는 정책 등장 & & $\mathrm{R}$ \\
\hline
\end{tabular}

※ R: Previous Research, P: Press, I: Depth Interview

상황에 부합하는 모델이 부재하다는 의견이 도출되었다. 스포츠전문가 및 기관 역량 요인을 살펴보면 언론기사 에서 스포츠전문가들의 체육 정책 프로그램에 참여, 전문 체육 유관기관인 한국스포츠정책과학원의 역할, 대한체 육회와 유관 기관들 간 업무 효율 등의 이슈는 정책 의제 설정과정에 영향을 미치는 것으로 나타났다.

전문체육 본질 요인의 경우 전문체육이 추구하고자 하 는 가치는 무엇이며, 존재의 목적에 대한 이슈와 관련이 있다. 선행연구에서는 전문체육 정책은 국민체육진흥기 금으로 운영되는 제도인 만큼 국민들이 전문체육에 대해 가지는 인식 등 엘리트 스포츠 본질에 대한 인식 또는 인 식의 차이가 정책 의제설정과정에 영향을 미치는 것으로 도출되었다.

\section{정책대안흐름}

다중흐름모형 중 정책대안흐름 관점에서 스포츠 관련
행정기구 개편, 우수선수양성지원 관련 정책 개편, 우수 선수양성지원 관련 정책의 상위 정책 및 제도 개편, 전문 체육선수 보상 제도, 전문체육선수 지원 제도, 종목별 특 성 및 형평성에 대한 공동체 공유 가치, 예산 설정, 이벤 트 유치 정책과 같은 요인이 도출되었다. 〈Table 6〉에서 구체적인 결과를 제시하였다.

스포츠 관련 행정기구 개편 요인의 경우 선행연구를 살펴보면 스포츠 유관 행정기구 신설 및 개편, 명칭변경 이 있어온 것으로 나타났다. 한국의 스포츠 관련 행정기 구는 1920년 조선체육회 출범을 시작으로 1948년 대한 체육회로 개칭되며, 1983 년 법정 법인 체육 단체로 출범 했다. 이후 국민체육진흥법 및 정부조직법의 개정으로 전 문체육의 체계적 육성을 위한 체육부가 발족했다. 점차 체육 담당 행정기구가 대폭 확대되었다. 체육청소년부, 문화체육부, 문화관광부, 문화체육관광부 등으로 명칭이 변경되어 왔다. 조직의 신설 또는 개편과 맞닿아 전문체 육 정책 업무의 주관 기관의 역량, 업무 분장, 효율성과 
관련한 정책의 흐름이 정책 의제화 단계에 영향을 미친 것으로 드러났다. 심층면담을 통해서는 이러한 변화속에 서 나타난 부정적 현상이 드러났다.

"지원금을 사용하는 카드를 특정 스포츠 시설에서만 사용 할 수 있어서 어려운 측면이 있습니다."

우수선수양성지원 관련 정책 개편과 상위 정책 및 제 도 개편 요인을 살펴보면 선행연구에서는 2010년 청소년 대표선수 정책 신설, 2015년 우수영재 육성사업 시행, 2016년 기초영재 육성사업 폐지 등과 같은 육성 정책의 개편이 하나의 예시로서 제시하였다. 또한 호돌이 계획, 김영삼 및 김대중 정부의 5 개년 계획, 이분형 스포츠 지 원정책 등은 엘리트 선수 육성 세부 정책을 아우르는 상 위 정책으로서 의제 설정 과정에 영향을 미치는 것으로 나타났다. 상위 제도로서 국민체육진흥법의 경우 전문체 육 육성, 월드컵 개최, 불안한 정치 사회 경제 안정을 위 해 제정되었고 의제화에 영향을 미친 것으로 도출되었다.

전문체육 선수를 위한 제도적 관점에서 살펴보면 선행 연구에서는 국가대표 연금제도 도입, 우수선수 보상제도 실시, 병역특례법, 특기자 제도 신설 등을 통해 선수들에 게 장려책을 주기 위한 노력이 나타난 것으로 드러났으며 정책 의제 설정 과정에 영향을 미친 것으로 나타났다. 심 층면담을 통해서는 지원적 측면에서 다음과 같은 내용이 도출되었다. 중복으로 나타난 의견의 경우 접근성 및 전 문성 갖춘 시설 확충의 필요성이 5 회, 각 종목 및 각 단계 별 특성화된 프로그램 수립 필요에 대한 내용이 12 회 제 시되었다.

"저희 종목은 한 종목안에도 다양한 세부종목들이 있어 각 세부종목별로 적합한 훈련을 할 수 있는 시설이 갖추어진 훈 련장소가 부족한 실정입니다."

종목별 특성 및 형평성에 관하여 살펴보면 언론자료에 서는 인기종목과 비인기종목 간의 괴리가 있고 이러한 부 족한 부분을 채워주기 위한 보조장치가 필요하다는 의견 이 제시되었다. 선행연구에서는 각 종목 전문체육 선수별 로 특화별 훈련 프로그램이 부재하다는 내용이 제시되었 다. 심층면담 내용을 살펴보면 특성 반영과 형평성에 대 한 내용들이 도출되고 있다.
구체적으로, 연구 참여자들은 각 단계의 사업예산에 대한 적정성에 대한 평가가 필요하다는 점에 대해 4 인이 언급했다.

"집중훈련을 해야 할 시기에 선발기준 연령 때문에 선발하 지 못해 육성에 어려움이 있습니다. 선발기준 연령의 조절이 필요합니다."

"다른 종목과 조금 다르게 많은 장비가 사용되고 장비 컨디 션에 의해 승패가 결정될 수 있어 전문장비관리자의 지원이 필요한 실정입니다."

예산 설정과 국제 대회 유치 정책 요인의 경우 예산 설 정 측면에서 선행연구를 살펴보면 국가의 전문체육에 대 한 예산 규모, 편성 현황, 배분 체계 등은 정책 의제화에 영향을 미친 것으로 나타났고 경기단체들의 낮은 재정자 립도와 지원금의 투명한 집행 여부 역시 영향을 미친 것으 로 나타났다. 또한 국제 대회 유치 정책에 초점을 맞출 경 우 올림픽 유치를 위한 정책 등장, 동계/하계 올림픽 및 월 드컵 유치 필요성을 강조하는 정책들이 등장하여 이러한 부분이 의제 설정과정에 영향을 미친 것으로 나타났다. 심 층면담을 통해서도 지원과 관련된 내용이 도출되었다.

"저희는 사실 하나의 종목이지만 다양한 종목이 포함되어 있는 복합종목이며 이로 인해 관리 및 활용해야 하는 선수와 시설도 많지만 지원되는 예산은 한정적인 것 같습니다."

\section{정치흐름}

다중흐름모형 중 정치흐름 관점에서 국민 통합을 위한 전문체육, 국위선양을 위한 전문체육, 남북화해 협력을 위 한 전문체육, 정권변화에 따른 스포츠 행정기구 개편, 정 권 변화에 따른 전문체육 상위정책 변동과 같은 요인이 도 출되었다. 〈Table 7〉을 통해 자세한 결과를 제시하였다.

국민 통합/국위선양/남북화해 협력을 위한 전문체육 요인의 경우 선행연구를 살펴보면 의회의 이념과 국민의 여론, 행정부 교체 등과 같은 요인에 영향을 받은 것으로 나타났다. 이로 인해 군사 정권 집권 시기 국민 통합 원동 력을 마련하기 위해 국민체육진흥법을 입안하고 전문체 육을 통해 통합을 이룬다는 정책이 주류를 이루게 되었 다. 언론기사에서는 남북이 대치하는 상황에서 전문체육 
Table 7. Political Stream Perspective Results

\begin{tabular}{|c|c|c|}
\hline Component Factor_Korean & Factor & Source \\
\hline $\begin{array}{c}\text { 5.16군사혁명 이후 국민체육진흥을 통해 국민통합원동력을 마련, 국가발전 기본은 } \\
\text { 엘리트스포츠임을 강조 }\end{array}$ & \multirow{4}{*}{$\begin{array}{c}\text { Elite Sports } \\
\text { for Nation Integration }\end{array}$} & $\mathrm{R}, \mathrm{P}$ \\
\hline 국민통합을 위한 국민체육진흥법제정 & & $\mathrm{R}, \mathrm{P}$ \\
\hline 엘리트 스포츠 육성을 위한 3,4공화국 국민체육진흥법 3차례 개정 & & $\mathrm{R}$ \\
\hline $\begin{array}{c}\text { 3공화국 및 5공화국은 정권의 정당성을 위한 스포츠 수단화, 국수주의적 엘리트 스포츠 } \\
\text { 수립 }\end{array}$ & & $\mathrm{R}$ \\
\hline 3공화국은 스포츠가 국가에 의해 동원되는 국위선양의 수단으로 인식 & \multirow{4}{*}{$\begin{array}{c}\text { Elite Sports for Enhancing } \\
\text { National Prestige } \\
\text { (Cold War Context) }\end{array}$} & $\mathrm{R}, \mathrm{P}$ \\
\hline 남북대치 상황에서 정권 정당성 확보를 위한 남북 스포츠 대결 우위 확보 필요 & & $\mathrm{R}, \mathrm{P}$ \\
\hline 엘리트 스포츠는 정치적 측면에서 사회통합, 국위선양 등 순기능적 역할만 부각 & & $\mathrm{R}, \mathrm{P}$ \\
\hline 엘리트 스포츠는 국가목적 달성을 위한 저비용 고효율 정책 전략으로 인식 & & $\mathrm{R}, \mathrm{P}$ \\
\hline 노무현-김정일 정상회담 후 토리노 동계올림픽, 도하아시아경기대회 남북공동입장 & \multirow{3}{*}{$\begin{array}{l}\text { Elite Sports for Inter } \\
\text { Korean Reconciliation } \\
\text { and Cooperation }\end{array}$} & $\mathrm{R}$ \\
\hline 김대중 정부 남북 정상회담에 따른 남북 스포츠 교류 활성화 & & $\mathrm{R}$ \\
\hline 엘리트 스포츠는 한국의 분단국 상황과 정치 불안 우려 해소역할 & & $\mathrm{R}, \mathrm{P}$ \\
\hline 엘리트 체육의 체계적 육성을 위한 체육부 신설 & \multirow{6}{*}{$\begin{array}{c}\text { Sports Related } \\
\text { Government } \\
\text { Organization } \\
\text { Restructure } \\
\text { With Regime Change }\end{array}$} & $\mathrm{R}$ \\
\hline 정권 교체 후 체육국이 체육국제국으로 개편 & & $\mathrm{R}$ \\
\hline 전두환 정부 체계적 엘리트스포츠 육성을 위한 체육부 신설 & & $\mathrm{R}$ \\
\hline 이명박 정부는 문화체육관광부로 명칭변경 & & $\mathrm{R}$ \\
\hline 김대중 정부의 체육행정 조직 축소로 문화체육부가 문화관광부로 변경 & & $\mathrm{R}$ \\
\hline 작은 정부 구현에 따른 김영삼 정부의 문화부와 체육청소년부의 문화체육부 개편 & & $\mathrm{R}$ \\
\hline 새로운 정권이 들어설 때마다 엘리트 스포츠에 대한 평가가 다름 & \multirow{11}{*}{$\begin{array}{l}\text { Parent Policy Change of } \\
\text { Elite Sports With } \\
\text { Regime Change }\end{array}$} & $\mathrm{R}$ \\
\hline 박정희 정부 체육 스포츠 행정 강화 방침 & & $\mathrm{R}$ \\
\hline $\begin{array}{c}\text { 박정희/전두환 정권은 군국주의적 체육정책, 노태우 김영삼 정권은 과도기적 형태, } \\
\text { 김웅 우후는 선진국형 엘리트 스포츠를 지향 }\end{array}$ & & $\mathrm{R}, \mathrm{P}$ \\
\hline 문민정권 때부터 엘리트 스포츠 평가 절하 시작 & & $\mathrm{R}$ \\
\hline 스포츠 기본권 보장 등 관련 50대 중요 국정 과제에 들어가지 못함 & & $\mathrm{R}$ \\
\hline 제1공화국 정부차원의 뚜렷한 엘리트 스포츠 정책 부재 & & $\mathrm{R}$ \\
\hline 김영삼 정부의 5개년 계획(sport for all, 1993-1997) & & $\mathrm{R}$ \\
\hline 김대중 정부의 2차 5개년 계획(1998-2002) & & $\mathrm{R}$ \\
\hline 노무현 정부의 참여정부의 국민체육진흥 5 개년 계획 & & $\mathrm{R}$ \\
\hline 문민정부는 엘리트 스포츠에서 생활체육으로 전환하고자 국민체육진흥법개정 & & $\mathrm{R}$ \\
\hline 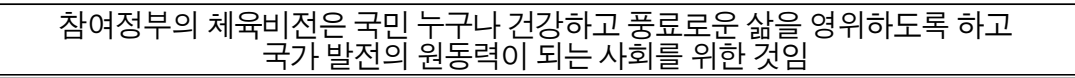 & & $\mathrm{R}$ \\
\hline
\end{tabular}

※ R: Previous Research, P: Press, I: Depth Interview

은 국위선양의 수단으로 인식되었으며, 대내외적으로 정 권의 정당성을 확보하는 국위선양의 측면을 강조하고자 하는 정치의 흐름이 있다는 부분을 강조하였다. 동시에 아이러니하게도 남북 화해 무드를 조성하기 위한 남북 협 력 도모의 수단으로도 전문체육을 인식하는 등의 정치의 흐름이 나타나 정책 의제 설정과정에 영향을 미친 것으로 나타났다.

정권변화에 따른 스포츠 행정기구 개편 요인을 살펴보 면 선행연구를 통해 전두환 정부는 체육부를 신설하고, 이명박 정부는 문화체육관광부로 부처의 명칭을 바꾸고,
김대중 정부는 문화체육부를 문화관광부로 행정기구를 개편한 부분을 확인할 수 있었다. 이러한 정치의 흐름은 정책 의제 설정에 영향을 미친 것으로 드러났다.

정권 변화에 따른 전문체육 상위정책 변동 요인에 초점 을 맞추면 선행연구에서 살펴볼 수 있듯이 상위 정책이란 김영삼 정부와 김대중 정부의 스포츠에 대한 5 개년 계획 또는, 노무현 정부의 국민체육진흥 5 개년 계획 등이 예시 가 될 수 있다. 또한 정권의 전문체육에 대한 인식과 평가 는 선행연구에 따르면 정책 기조에 반영되며 이러한 부분 은 정책 의제 설정과정에 영향을 미친 것으로 나타났다. 


\section{논 의}

한국 전문체육 정책 의제 설정에 영향을 미친 요인은 Kingdon (1984)의 다중흐름모형에서 제시한 문제, 정책, 정치의 흐름에서 크게 벗어나지 않았다. 다만 도출된 결과 는 전문체육 정책이라는 특수한 영역으로 인해 다중흐름모 형과는 달리 고려해야할 필요가 있는 부분이 도출되었다.

우선 전문체육 정책 의제 설정과 관련한 현상을 문제, 정책, 정치의 흐름으로 명확하게 구분해 내기 어려웠다. 왜냐하면 각각 흐름에 중복되어 해당하는 요소들이 존재 했기 때문이다. 특히 세부 요인 중 가장 눈에 띄는 것은 국제 스포츠 대회와 관련한 요인들이다. 국제 스포츠 대 회 개최는 현상, 이벤트 요인으로 볼 수 있어 문제의 흐름 으로 구분될 수 있다. 동시에 국제스포츠 대회 유치의 경 우 행정부의 기조인 정치로 해석될 여지도 있을 뿐 아니 라 스포츠 대회 유치 정책으로써 정책의 흐름으로 구분할 수도 있다. 이는 국제 스포츠 대회가 전문체육 정책 의제 설정 과정에 영향을 미칠 수 있는 문제, 정책, 정치 전반 을 아우르는 요소로 작용한다고 볼 수 있다. Kingdon (1984)의 다중흐름모형을 통해 해석해 보자면 국제 스포 츠 대회는 정책, 문제, 정치의 흐름인 동시에 정책의 창 역할을 하는 것으로 치환시켜 생각 해 볼 수 있다.

이와 함께 정책과 관련한 이해관계자들 사이의 엘리트 스포츠 본질에 대한 인식은 때로는 문제의 흐름으로 때로 는 정책 또는 정치의 흐름으로 전문체육 정책 의제화에 작용했다. 구체적으로 살펴보면 문제의 흐름 관점에서는 메달 지상주의로 인식, 국가 목적 달성을 위한 고효율 정 책으로 인식하여 등장했으며 정책의 흐름에 있어서는 국 제 대회 유치를 위한 정책의 일부가 되거나, 정치의 흐름 에 있어서는 국위선양을 위한 매개이거나 남북 대치상황 에서는 정권의 우월성 및 정당성을 확보하게 해주는 매 개, 남북 화해 분위기에서는 평화와 협력을 촉진하는 촉 매자로 인식되었다. 전문체육의 본질 그 자체가 문제이자 정책, 정치로 변모하여 엘리트 스포츠 정책 의제화 과정 에 작용해왔다.

마지막으로 연구를 진행하면서 알게 된 전문체육 정책 의제화에 있어 새롭게 발견한 문제는 개별 전문체육 정책 또는 유관 정책들의 상위 정책의 부재다. 다시 말해 흔히 들 언급하는 경제 정책 기조, 외교 정책 기조와 같은 정책 기조(policy paradigm)에 비해 전문체육 분야에서는 이 를 전문체육에 국한된 기조라고 구분 짓기 보다는 스포츠 외교, 경제 및 사회 발전 기조 등과 혼용되어 나타나는 경 우가 많았다.

각 흐름별로 살펴보면 정책문제의 흐름을 구성하는 세 부 요인으로 국제스포츠 대회 성적, 국제스포츠 대회 개 최, 전문체육선수 수급, 선수 및 종목 지원 시스템, 학생 학습권/학생인권/학원 스포츠, 정책의 현실성, 엘리트스 포츠 전문가 및 기관역량, 엘리트 스포츠 본질에 대한 인 식이 도출되었다. 구체적으로 세계에 한국을 알리기 위해 서, 보다 구체적으로는 국제스포츠 대회 성적 향상을 위 해 우리 정부는 선수양성의 과학화, 체계적 양성 등이 필 요하다는 관점에서 엘리트체육 진흥정책에 집중했다는 선행연구(Kim, 2015; Lee, Kim, \& Lee, 2005)와 같은 맥락에서 국제스포츠 대회 성적은 문제의 흐름을 구성하 는 세부요인으로 도출되었다. 또한 국제스포츠 대회 개최 및 파견도 우수선수 양성정책에 영향을 미친다는 선행연 구(Lee et al., 2001)와 같이 본 연구에서도 해당 요인들 의 문제의 흐름을 구성하는 요인으로 나타났다. 더하여, 전문체육선수 수급의 어려움이 문제로 인지되어 시스템 개선이 필요하다는 지적에서 다양한 정책들이 계획되고 실행되었던 것처럼 (Lim et al., 2010) 본 연구 결과 전문 체육선수 수급의 어려움이 문제의 흐름을 구성하는 요인 으로 도출되었다. 선수 및 종목지원시스템 역시 선행연구 에서 우수선수양성지원 정책과 관련하여 생활체육과 학 교체육, 전문체육간의 선순환적 구조가 불명확함을 지적 한 것(Park, 2016b)과 마찬가지로 본 연구에서도 문제 의 흐름을 구성하는 요인으로 도출되었다. 마지막으로 우 수선수정책과 관련하여 학생선수는 일반 학생에 비해 수 학 교과 내용을 어려워하거나, 일반 교사의 학생선수에 대한 지도 어려움, 학생선수 학습지원 문제 등 기존 연구 에서 학생학습권/인권/학원스포츠에 대한 문제가 지적되 어 왔다(Hong, 2013b). 본 연구결과를 통해서도 학생학 습권, 학생인권, 학원 스포츠는 우수선수양성 정책 의제 화에 영향을 미치는 문제의 흐름을 구성하는 세부요인으 로 도출되었다. 연구 결과 도출된 정책의 현실성 요인은 선수 지도자 등의 현장 목소리를 반영하는 정책 보다는 하향식(Top-down approach)의 민주적 참여가 결여된 정책이 문제라 지적한 선행연구(Kim, 2015)와 맥을 같 
이 한다. 연구결과 선행연구에서 문제로 언급된바와 같이 스포츠 전문가들의 정책 의제설정 및 의사결정 과정에 대 한 참여 부족도 요인으로 도출되었으며(Lee, 2006), 사 회 문화 구조 내에서 엘리트 스포츠 본질에 대한 인식도 문제의 흐름을 구성하는 것 $(\mathrm{Na}, 2002)$ 으로 나타났다.

정책대안의 흐름을 구성하는 세부요인으로는 스포츠 관련 행정기구의 개편, 우수선수양성지원 정책/상위정책 /제도, 우수선수를 위한 제도(지원 및 장려책(Incentive)), 종목별 특성에 대한 정책공동체의 가치, 예산, 국제대회 유지 정책이 도출되었다. 선행연구에서 지적한 것과 마찬 가지로 체육부 발족, 문화관광부 등으로의 명칭 변경등과 같이 행정기구의 개편 우수선수양성 정책에 영향을 미친 것으로 $(\mathrm{Kim}, 2013)$ 언급된것과 같이 본 연구에서는 정 책 대안의 흐름을 구성하는 요인으로 나타났다. 또한 우 수선수양성지원 정책, 제도 등의 개편 역시 정책 대안의 흐름을 구성하는 요인으로 도출되었으며 이는 선행연구 들의 결과와 맥을 같이 했다(Son \& Yu, 2009; Son \& Shin, 2008b; Lee, Ju, \& Kim, 2001). 우수선수를 위 한 장려책 및 지원 활동은 정책 대안의 흐름을 구성하는 요인으로 나타났으며 선행연구에서도 상무제도, 병역특 례법, 연금제도, 특기자 제도 등이 우수선수양성 정책 의 제설정에 영향을 미친 요인으로 본 것과 크게 벗어나지 않았다(Kim \& Kim, 2013; Lee, 2015). 종목별 특성 및 형평성에 대한 정책공동체의 가치는 우수선수양성과 관 련한 정책 대안의 흐름을 구성하는 것으로 도출되었으며, 이는 Lim et al. (2010)의 연구에서도 지적한 엘리트 선 수 단계에 맞는 프로그램이 부족한 것이라는 지적과 같은 맥락이다. 또한 정책 대안 흐름을 구성하는 요인으로 예 산이 도출되었는데 이는 체육기금의 안정적인 확보, 예산 집행의 효율성, 예산의 일관성 등이 우수선수양성 정책에 직간접 영향을 미친다는 선행연구 결과에서 벗어나지 않 았다(Kim \& Kim, 2009, Lee, 2015). 올림픽 등 국제대 회 유치 정책이 우수선수양성 정책 대안 흐름에 영향을 미치는 세부요인으로 도출되었으며 선행연구들이 언급 한 요인들과 유사한 결과를 나타냈다(Kim, 2000, Lee et al., 2001).

정치의 흐름을 구성하는 세부요인으로는 국민통합 필 요에 따른 전문체육, 남북대치 및 화해와 관련한 체육, 정 권 변화에 따른 스포츠 관련 행정기구 개편, 정권 변화에
따른 전문체육 상위 정책 변동이 도출되었다. 국민통합을 위한 전문체육을 강조하며 정권의 정당성 확보를 위한 정 치의 흐름이 우수선수양성 정책 의제설정에 영향을 미친 것으로 연구 결과가 도출되었다. 선행연구들도 국민통합 을 강조하는 정치적 요인들이 우수선수양성 정책에 영향 을 미쳤다는 결과를 나타냈다(Kim, 2000; Kim, 2015). 남북 대치 및 평화 상황에서 파생되는 정치적 환경 요소들 역시 우수선수양성 정책 의제 설정에 영향을 미친 것으로 나타났으며 해당 요인들은 선행연구에서도 동일하게 언급 된 요인들이었다(Kwon, 2004; Kim \& Kim, 2013; Yu, 2004). 우수선수양성 정책 의제설정에 영향을 미치는 정 치 흐름 구성 요인으로 정권 변화에 따른 스포츠 관련 행 정기구의 개편이 도출되었다. 이는 선행연구에서 언급된 체육국의 체육국제국 개편, 체육청소년부의 문화체육부 개편 등과 같은 변화가 우수선수양성 정책에 영향을 주었 다는 연구결과에서 크게 벗어나지 않았다(Kim, 2000; Kim \& Kim, 2001; Lee et al., 2001). 김영삼 정부, 김 대중 정부, 노무현 정부 각각의 국민체육진흥과 관련한 정 책 또는 계획들은 우수선수양성 정책에 영향을 미치는 것 으로 도출된 선행연구(Moon, 2019; Choi \& Kim, 2011)의 결과와 마찬가지로 본 연구 결과 정권 변화에 따 른 상위정책 변동은 우수선수양성정책 의제설정에 영향을 미치는 요인으로 도출되었다.

본 연구의 결과에 따른 학문적 의의는 기존 우수선수 양성지원 정책의 문제점이 야기되는데 근본이 될 수 있는 초기 정책 수립 단계에서 영향을 미친 요인을 제시하였다 는 부분이다. 해당 연구는 추구 우수선수양성지원 정책의 문제점에 대한 이론적 해석과 이를 통한 해결 방안을 제안 하는데 있어 기반이 될 수 있다.

더 나아가 다중정책흐름모형 측면에서는 전문체육 정 책 중에서도 우수선수양성지원 정책에 초점을 맞추어 모 형을 적용해 봄에 따라 해당 모형이 스포츠 영역에서 일 반화되는데 있어 긍정적 영향을 미쳤다. 이러한 결과를 바탕으로 하며 다른 정책 또는 보다 세부적인 정책들에도 해당 모형을 적용하여 상황을 설명해 낼 수 있을 것으로 판단된다.

실무적인 측면에서 살펴보면 해당 결과를 통해서 정책 문제, 정책대안, 정치 흐름 속에서 다양한 요인들이 정책 의제를 설정하는데 있어 영향을 미칠 수 있다는 것을 알 
게 되었다. 이러한 요인들을 잘 고려하여 정책을 새롭게 수립 또는 기존의 문제점을 보완해 나가는 방향으로 정책 을 수정하는데 필요한 관계자들의 의견들을 정확히 파악 할 수 있고 적재적소에 이러한 의견을 반영해 나갈 수 있다.

더 나아가 정책을 모니터링하는 경우에도 정책 의제를 설정해 나가는데 영향을 미치는 요인들을 고려할 수 있 다. 이러한 요인들을 고려함에 따라 불필요한 부분을 최 소화 시켜 명확히 정책이 나아가는 방향과 실행 상황에 대해 평가해 나갈 수 있다.

\section{결론 및 제언}

본 연구는 정책 의제 설정 과정을 설명하는 다중흐름 모형을 통해 전문체육 정책 수립을 위한 첫 단계인 의제 설정과정에 영향을 미치는 요인을 도출하고자 했다. 이를 위해 질적연구 접근으로 선행연구, 심층면담, 언론자료 을 통해 자료를 수집하였다. 내용분석을 통해 요인을 도 출하고 이를 기반으로 단계별 범주화 및 항목화를 통해 Kingdon (1984)의 다중흐름모형에 기반하여 문제, 정 책, 정치의 흐름이라는 관점을 기준으로 각각의 주요요인 을 도출했다.

그 결과 한국 전문체육 정책에 영향을 주요 요인의 문 제, 정책, 정치 흐름을 구성하는 관점에서 각각의 주요요 인을 도출할 수 있었다. 먼저, 정책문제흐름의 경우 국제 스포츠 대회 성적, 국제 스포츠 대회 개최 및 참가, 전문 체육선수 수급, 전문체육선수 및 종목 지원 시스템, 학생 학습권/인권/학원 스포츠, 정책의 현실성, 스포츠 전문가 및 기관의 역량, 전문체육에 대한 인식이 세부 요인으로 나타났다.

둘째 정책 흐름의 경우 스포츠 행정기구 개편, 전문체 육선수 육성 정책, 상위 정책 및 제도개편, 전문체육선수 를 위한 장려책 및 지원제도, 종목별 특성 및 형평성에 대 한 정책공동체의 가치, 예산, 국제 대회 유치 정책이 세부 요인으로 도출되었다.

마지막으로 정치의 흐름을 구성하는 세부 요인은 국민 통합/국위선양/남북화해 협력을 위한 전문체육, 정권변 화에 따른 스포츠 행정기구 개편, 정권 변화에 따른 전문 체육 상위정책 변동으로 나타났다.
다만, 본 연구가 가지는 결과, 자료수집 기간 및 범위, 일반화 및 개별화와 관련한 한계점과 관련하여 향후 연구 는 다음의 사항을 고려하여 진행해 볼 수 있을 것이다. 첫 째, 본 연구에서 도출된 요인들 간의 중요도 및 관계를 알 아보는 연구를 진행해 볼 수 있다. 한국 전문체육 정책 의 제 설정과정에 영향을 미친 요인을 알아보기 위해 동 연 구는 다중흐름모형에서 제시한 주요 요인에 기반하여 세 부 요인을 도출했다. 도출한 요인들 간의 관계 및 영향력 을 비교하여 현실을 잘 설명하는 설득력 있는 모델을 제 안할 수 있는 연구가 필요하다.

둘째, 본 연구는 전문체육 정책 전반을 대상으로 정책 의제화에 작용하는 요인을 도출했다. 향후 연구에서는 개 별 세부 전문체육 정책을 각각 분석하여 의제화에 영향을 미치는 요인을 도출하여 본 연구의 결과와 비교분석해 볼 수 있다.

셋째, 본 연구는 전문체육 정책 의제 설정 과정에 영향 을 미치는 요인을 도출했다. 정책 사이클을 고려한다면 의제 설정 다음 단계인 정책 수립 및 집행 단계 등과 같은 각 단계들에서 영향을 미치는 요인들을 도출하여 각 정책 단계에서 영향을 미치는 요인들을 비교분석 하는 연구를 진행해 볼 수 있다.

한국의 전문체육은 국내외 정치, 사회, 문화적 맥락과 밀접하게 맞닿아 부침을 거듭해왔다. 한국 전문체육 정책 에 대한 적극적인 연구 활동이 전문체육 본질에 대한 사 회적 합의와 공감대 형성에 기여하여 궁극적으로 전문체 육 기저 문화의 핵심 요소로 공고화되길 기대한다.

\section{참고문헌}

Altheide, D. L., \& Schneider, B. (1996). Process of qualitative document analysis. Qualitative media analysis, 23-41.

Choi, G. (2011). 경기력 G7 시대 엘리트 스포츠 경기력 육성방향, 스포츠선진국을 향한 엘리트체육 육성방안 (Korean Title Only). Sports Science, 117, 2-10.

Choi, H. \& Kim, J. (2011). The Study on Characteristics of Revised National Promotion Law for Sport in 1980s. Journal of Korean Society for the Sociology of Sport, 46(1), 153-162.

Choi, M. (2016). The Critical Consideration of the Career Support Project for Retired Athletes. Korean journal of physical 
education, 55(1), 75-96.

Choi, S. \& Park, M. (2010). 정책연구에서의Kingdon 정책흐름모 형의 적용 현황과 적실성에 대한 소고(Korean Title Only). Korean Association for Public Administration Conference, 91-106

Choi, U. (2011). 경기력 G7 시대 엘리트 스포츠 경기력 육성방향; 권역별 스포츠영재 발굴, 육성 현황 및 미래 방향 (Korean Title Only). Sports Science, 117, 11-18.

Cho, J. (2013). Elite Sport in South Korean Society -Consequences of the 1988 Seoul Olympic Games-. Journal of Korean Society for the Study of Physical Education, 18(2), 1-14.

Creswell, J. W. (2003). Research Design: Qualitative. Quantitative, and mixed methods. Sage Publications.

De Bosscher, V., De Knop, P., Van Bottenburg, M., \& Shibli, S. (2006). A conceptual framework for analysing sports policy factors leading to international sporting success. European sport management quarterly, 6(2), 185-215.

Eagleman, A. M. (2011). Stereotypes of race and nationality: A qualitative analysis of sport magazine coverage of MLB players. Journal of sport management, 25(2), 156-168.

Hong, E. (2012). Applying a Western-based policy community framework to the analysis of South Korean elite sport policy: The role of businesses and armed forces. International journal of sport policy and politics, 4(1), 23-37.

Hong, E. (2013a). An Exploration of School Physical Education Policy by Establishing the Definition of School Physical Education Welfare. Korean journal of physical education, 52(4), 437-448.

Hong, S. (2013b). A Study on Improvement and Problem of Policy for Learning Support of Student-Athlete. Journal of Korean Society of Sport Policy, 27, 75-88.

Hwang, H. (1991). 우수선수육성 실태: 차세대 국가대표양성 실종 우려된다 (Korean Title Only). Physical Education, 271, 16-21.

Jung, H. (2017). Toward a preliminary conceptualization of 'youth sport policy'. Korean Journal of Sport Science, 28(4), 944-962.

Jung, J. \& Kim, D. (2003). Processing and Prospect of Korean Sport Policies. Korean journal of physical education, 42(4), 59-69.

Jung, J., Ko, B., Kim, Y., Kim, K., Seo, T., Nam, S., Ko, E., Lee, W., Kwon, K., Lee, K. (2017) 엘리트선수 양성시스템 개선방안 연구 (Korean Title Only). Unpublished Working Report, Korea Institute of Sport Science.

Jung, Y., Choi, M., \& Lee, Y. (2016). A Study on the reactivating
Plans of Promoting Project on the Basic Sports Gifted Children in the Elementary School. Journal of Korean Society of Sport Policy, 39, 115-129.

Kang, C. \& Lee, J. (2004). The Products and Prospectis of Korean Elite Sports. Korean Society for the Philosophy of Sport, Dance \& Martial Arts, 12(2), 401-417.

Kim, D. (2000). The Process and Prospect of Elite Sport Policies according to Political Transitions in Korea. Korean Society for the Philosophy of Sport, Dance \& Martial Arts, 8(1), 181-199.

Kim, D. (2003). 한국 엘리트스포츠정책의사회, 철학적 진단과발 전과제 (Korean Title Only). Journal of Korean Society of Sport Policy, 1, 15-26.

Kim, Y. (2015). Finding Pointing Spot of Korean Sports Culture and Alternative to its Advancement. Korean Journal of Physical Education, 54(1), 47-56.

Kim, B. \& Kim, S. (2013). The Improvement Direction of Elite Athletes Development-Related Institutions. Sports Science, 31(1), 21-28.

Kim, D. \& Kim, C. (2001). A Comparative Study of Central Administrative Organizations for Physical Education in South and North Korea, The Korean Society of Sports Science, 10(2), 291-300.

Kim, D. \& Park, J. (2008). Lee Administration's Vision and Challenges for Elite Sport. Journal of Korean Society of Sport Policy, 11, 1-19.

Kim, D. (2000). 정치상황 변화에 따른 한국 엘리트스포츠 정책의 전개양상과 전망 (Korean Title Only). Korean Society for the Philosophy of Sport, Dance \& Martial Arts, 8(1), 181-199.

Kim, D. (2012). A Study on the Development of School Elite Sports. Journal of Korean Society of Sport Policy, 10, 17-35.

Kim, D., Yu, H., \& Song, G. (2008). A Study on Elite Player Cultivation by the New Government and the Directions for Relevant National Policy. KOREASPORT SOCIETY, 1(1), 27.

Kim, H. \& Kim, H. (2009). A Study on the Budget Management in Physical Activity Policies of the Participatory Government. The Korean Society of Sports Science, 18(3), 17-30.

$\mathrm{Kim}, \mathrm{J}$. (2003). 엘리트스포츠 육성, 체육 정책의 핵심이 되어야 (Korean Title Only). Sports Science, 83, 2-6.

Kim, K. \& Choi, K. (2015). Present Status of Korea’s Sports Talented Program. Asian Journal of Youth Sport, 2(1), 29-36.

Kim, K. (2014). Policy Suggestions for Athlete's Career Development and Transition: A Case of German Support Program for Athlete's Dual Career. Journal of the korean 
association of certified exercise professionals, 16(4), 101-113. Kim, M. (2013). Taenung Training Center: The Cradle of Korean Elite Sports(1966-2000). Korean Society for History of Physical Education, Sport and Dance, 18(2), 127-140.

Kim, S., Jang, S., \& Son, S. (1993). 엘리트스포츠 정책의바람직한 방향설정에 관한 연구 (Korean Title Only). Gunsan University, 20, 163-180.

Kim, S., Won, Y., \& Jung, H. (1999). Exploring To The Direction of Korean Sport under " IMF " Economic Crisis. Korean journal of physical education, 38(1), 569-578.

Kim, T. \& Park, I. (2004). Research Positive Points and Negative Points on Physical Education Policy in 5th Republic of Korea - Lay Elite Sports Upbring on. Journal of Korean Society of Sport Policy, 4, 99-123.

$\mathrm{Kim}, \mathrm{T}$. (2004). 참여정부 체육정책의 비전과 과제(Korean Title Only). KOREA SPORT SOCIETY Conference, 2004(1), 3-18.

Kim, Y. \& Kim, H. (2013). A Study on the Park Geun-hye government policy toward North Korea and Inter-Korean Sports Exchanges and Cooperation Promotion Plan. Korean Association of Sport and Entertainment Law, 7(4), 285-300.

Kim, Y. (2015). Reality and Task of Korean Sports Culture (3): Operation Mechanism and Pointing Spot of Elite Sports. Korean Society for the Philosophy of Sport, Dance \& Martial Arts, 23(2), 221-233.

Kingdon, J. W. (1984). Agendas, Alternatives, and Public Policies. Little, Brown and Company: Boston.

Ko, B. (2014). Sports Talent Identification and Selection in Korea. International Journal of Applied Sports Sciences, 26(2).

Krefting, L. (1991). Rigor in qualitative research: The assessment of trustworthiness. American journal of occupational therapy, 45(3), 214-222.

Kwon, O. (2004). Park's Military Regime and Sports Nationalism of Kim Taek-su. Korean Society for the Philosophy of Sport, Dance \& Martial Arts, 12(2), 385-400.

Lee, B., Oh, J., \& Kim, J. (1999). 효율적인 엘리트체육정책 방안 에 관한 연구(Korean Title Only). Yong In Univeristy Journal, 17, 101-122.

Lee, J. (2005). A Social Historical Study on the Policy Orientation of Elite Sport in Korea during the 1960's-1970's. Korean journal of physical education, 44(5), 43-54.

Lee, J., Kim, B., Kim, Y., Mun, Y., Lee, M., Lee, S., \& Kim, B. (2001). 국제경쟁력 강화를 위한 엘리트 체육 발전 모델 연구 (Korean Title Only). Korean Journal of Sport Science, 12(2),
56-78.

Lee, J., Kim, Y. (2004). Suggestions on selection profiles for early talent identification in sports. Korean Society of Sport Policy, 4, 17-43.

Lee, J., Yun, Y., Kwak, C., \& Lee, J. (2014). 새행정학2.0 (Korean Title Only). Deawon Publications: Seoul.

Lee, K. (1993). 우리나라 엘리트 체육정책의 변화를 통해본 진흥 방향 (Korean Title Only). Korea National Sport University Research Center Journal, 11, 1-11.

Lee, K., Kim, I., \& Lee, N. (2005). Structural Problems in Event Management of National Sports Festival and the Decline of University's Elite Sport in Local. Journal of Korean Society for the Sociology of Sport, 18(1), 165-177.

Lee, O., Ju, D., \& Kim, D. (2001). A Comparison of Nationalistic Sports Policies between the Third and Fifth Republic Governments in Korea. Korean Society for the Philosophy of Sport, Dance \& Martial Arts, 9(2), 105-124.

Lee, S. (2006). The Influence of Physical Educational Majors` professional perception in Public sports management office on their job alienation. Journal of Sports Science Research, 24, 75-90.

Lee, Y. (2013). An study on effectiveness evaluation of elite sports policy. Journal of Korean Society of Sport Policy, 11(1), 1-13.

Lee, Y. (2015). Role and Task of National Sports Promotional Funds for Bringing up the Elite Sports. Journal of Korean Society of Sport Policy, 13, 103-115.

Lee, Y., Jung, Y., Choi, M., Park, S., \& Jo, H. (2016). 체육영재육성 사업 중장기 발전계획 수립방안 (Korean Title Only). Unpublished Working Report, National Sports Promotion Corporation.

Lee. J. \& Kim, Y. (2004). Suggestions on selection profiles for early talent identification in sports. Journal of Korean Society of Sport Policy, 4, 17-43.

Lee. J. (1997). Study on the Physical Education Policy and Expansion of the Third Government of the Republic of Korea. Unpublished Doctoral Dissertation, Seoul National University.

Lim, J. (1999). A Study of Systematical Problem about Elite Player Program. Korean Journal of Physical Education, 230-235.

Lim, S. \& Huh, J. (2009). A Critical Review of the Literature on Sports and Physical Education Policies in the Third Republic of the Republic of Korea. The Korean Association of Sports Law, 12(1), 105-130. 
Lim, S., Lee, H., \& Lee, W. (2010). The Result, Problem and Future Challenges of Training Sport Gifted. Korean journal of physical education, 49(6), 91-102.

Lincoln, Y. S., \& Guba, E. G. (1985). Naturalistic Inquiry. CA: Sage.

Merkel, U. (2009). Sport, politics and reunification-a comparative analysis of Korea and Germany. The International Journal of the History of Sport, 26(3), 406-428.

Moon, G. (2019). The Significance of 100th Korean National Sports Festival and A Plan Introduction for Sport Business. Korean Society of Sports Science, 28(6), 653-670.

Na, S. (2002). Structural Transformation of sport organizations. The Korean Society of Sports Science, 11(2), 57-64.

Park, G. \& Kim, T. (2017). A Study on the Development of Taekwondo in the Middle \& High Schools according to the Sports Promotion Policies. Korea Journal of History of Physical Education, Sport and Dance, 22(4), 45-57.

Park, J. \& Han, S. (2011). Exploring Policy Factors Leading to Elite Sporting Success: A Theoretical Review at the Meso-Level. Korean Journal of Sport Science, 22(4), 2492-2506

Park, J. \& Park, H. (2011). A Study of a Case of Sport Policy Change with the Application of Kingdon's Policy Stream Framework: Focused on Local Public Sports Facilitates(Baseball Stadium)-related Law Revisions. Korean journal of physical education, 50(6), 113-127.

Park, J. (2016a). Policy Keynotes for the Integration of Sport Organizations. Korean Society of Sport Policy, 14(1), 65-76.

Park, J. (2016b). The Vision and Policy Objectives: Criticism and Tasks of the Korean Olympic Committee. Korean Society for the Philosophy of Sport, Dance \& Martial Arts, 24(4), 155-172.

Park, J. (2019). Direction of Physical Education in Schools for the Promotion of Elite Sports. Journal of Korean Society of Sport Policy, 17(4), 97-114.

Park, J. W., \& Lim, S. (2015). A chronological review of the development of elite sport policy in South Korea. Asia pacific journal of sport and social science, 4(3), 198-210.

Park, J. W., Lim, S. Y., \& Bretherton, P. (2012). Exploring the truth: Acritical approach to the success of Korean elite sport. Journal of sport and social issues, 36(3), 245-267.

Seo, J. \& Park, C. (2011). A Study on the Sports Administration and Policy of Roh Moo Hyun Government. Korean Society of Sports Science, 20(3), 819-833.

Shin, H. (2009). AStudy on Background of Full Amendment about
National Sports Promotion Act in the Fifth Republic of Korea. The Korean Association of Sports Law, 12(1), 151-169.

Son, S. \& Shin H. (2008). Protection of Sport Rights and Legal Change for the National Sport Promotion ; A Study on Enactment and Changing Process of National Sports Promotion Act. The Korean Association of Sports Law, 11(4), 253-271.

Son, S. \& Shin, H. (2008a). A Study on Intention and Background of Enactment of National Sports Promotion Act. The Korean Association of Sports Law, 11(3), 135-150.

Son, S. \& Shin, H. (2008b). Protection of Sport Rights and Legal Change for the National Sport Promotion ; A Study on Enactment and Changing Process of National Sports Promotion Act. Korean Association of Sport and Entertainment Law, 11(4), 253-271.

Son, S. \& Yu, D. (2009). A Study on the Sportsmen \& Women's Mutual-aid Association Law. Journal of Korean Society for the Sociology of Sport, 37(1), 231-241.

Son, S. (2011). A legal study on the special case of military service in athletes. Journal of Korean Society of Sport Policy, 9(2), $109-121$

Tak, M. (2018). Three conceptual tools for studying sports-related social/policy institutions: Costs, paths and grains. Journal of Korean Society for the Sociology of Sport, 31(1), 171-196.

Won, H. J., \& Hong, E. (2015). The development of sport policy and management in South Korea. International journal of sport policy and politics, 7(1), 141-152.

Yeon, K. (2008). Protection of Sport Rights and Legal Change for the National Sport Promotion; Structure for the Enactment of Fundamental Law of Sport in Korea. The Korean Association of Sports Law, 11(4), 113-143.

Yeun, K. (2011). Legal Issues on the Enactment of the School Physical Education Promotion Act. The Journal of Sports and Entertainment Law, 14(2), 117-157.

Yeun, K. (2016). The Protection of Sports Fundamental Rights and Legislation of the Basic Sports Law in Korea. International Sports Law Review Pandektis, 11.

Yu, U. (2005). 엘리트체육 육성을 위한 체육단체의 기능과 역할 (Korean Title Olny). Sports Science, 90, 9-15.

Yu, Y. (2004). 남북한 체육교류의 평가 및 방향 (Korean Title Only). Korea Society Studies, 7, 25-55. 


\title{
전문체육정책 의제설정과정에 영향을 미치는 요인에 대한 탐험적 분석 : 우수선수양성지원 정책을 중심으로
}

\author{
강지현 ${ }^{1}$, 손정화 $^{2}$, 신호진 $^{2}$, 권기성 ${ }^{3}$ \\ ${ }^{1}$ 서울대학교 박사과정 \\ ${ }^{2}$ 서울대학교 석사과정 \\ 3강원대학교 조교수
}

〔목적〕 본 연구는 정책 의제 설정 과정을 설명하는 다중흐름모형을 통해 전문체육 정책 수립을 위한 첫 단 계인 의제설정과정에 영향을 미치는 요인을 도출하고자 했다. 〔방법) 이를 위해 질적연구 접근으로 선행연구, 언론자료, 심층면담을 통해 자료를 수집하였다. 내용분석을 통해 요인을 도출하고 이를 기반으로 단계별 범주 화 및 항목화를 통해 Kingdon (1984)의 다중흐름모형에 기반하여 문제, 정책, 정치의 흐름이라는 관점을 기준으로 각각의 주요요인을 도출했다.〔결과〕 결과를 살펴보면 한국 전문체육 정책에 영향을 주요 요인의 문제, 정책, 정치 흐름을 구성하는 관점에서 각각의 주요요인을 도출할 수 있었다. 먼저, 문제흐름의 경우 국제 스포츠 대회 성적, 국제 스포츠 대회 개최 및 참가, 전문체육선수 수급, 전문체육선수 및 종목 지원 시스템, 학생 학습권/인권/학원 스포츠, 정책의 현실성, 스포츠 전문가 및 기관의 역량, 전문체육에 대한 인식이 세부 요인으로 나타났다. 둘째 정책 흐름의 경우 스포츠 행정기구 개편, 전문체육선수 육성 저책, 상위 정책 및 제도 개편, 전문체육선수를 위한 인센티브 및 지원제도, 종목별 특성 및 형평성에 대한 정책공동체의 가치, 예산, 국제 대회 유치 정책이 세부 요인으로 도출되었다. 마지막으로 정치의 흐름을 구성하는 세부 요인은 국민 통합 /국위선양/남북화해 협력을 위한 전문체육, 정권변화에 따른 스포츠 행정기구 개편, 정권 변화에 따른 전문체 육 상위정책 변동으로 나타났다. 〔결론) 한국 전문체육 정책에 대한 해당 연구 결과와 추후의 적극적인 연구 활동이 전문체육 본질에 대한 사회적 합의와 공감대 형성에 기여하여 궁극적으로 전문체육 기저 문화의 핵심 요소로 공고화되는데 도움이 될 수 있을 것으로 사료된다.

주요어: 전문체육 정책, 전문체육선수, 우수선수양성지원 정책, 다중흐름모형, 정책 의제 설정 